Article

\title{
Benthic Nutrient Fluxes from Mangrove Sediments of an Anthropogenically Impacted Estuary in Southern China
}

\section{David Kaiser ${ }^{1,2, *}$, Nicole Kowalski ${ }^{2, \dagger}$, Michael E. Böttcher ${ }^{2, \dagger}$, Bing Yan ${ }^{3}$ and Daniela Unger ${ }^{1, \sharp}$}

1 Leibniz Center for Tropical Marine Ecology, Fahrenheitstr. 6-8, D-28359 Bremen, Germany; E-Mail: daniela.unger@desy.de

2 Leibniz Institute for Baltic Sea Research, Seestr.15, D-18119 Warnemünde, Germany; E-Mails: nicole.kowalski@io-warnemuende.de (N.K.); michael.boettcher@io-warnemuende.de (M.E.B.)

3 Guangxi Mangrove Research Center, Guangxi Marine Environment \& Coastal Wetland Research Center, 92 Chang Qing Dong Lu, Beihai 536000, Guangxi, China; E-Mail: gxybing@tom.com

$\dagger$ These authors contributed equally to this work.

* Present address: Deutsches Elektronen-Synchrotron, Notkestraße 85, D-22607 Hamburg, Germany.

* Author to whom correspondence should be addressed; E-Mail: david.kaiser@io-warnemuende.de or david.kaiser.82@gmail.com; Tel.:+49-381-5197-306; Fax:+49-381-5197-302.

Academic Editors: Joseph M. Smoak and Christian Joshua Sanders

Received: 5 May 2015 / Accepted: 16 June 2015 / Published: 23 June 2015

\begin{abstract}
Mangroves serve as either sinks or sources for inorganic and organic nutrients and can mitigate anthropogenic nutrient pollution, control the production in adjacent systems, and prevent eutrophication. To better understand the nutrient dynamics in a subtropical mangrove, we employed a three-way approach in the Nanliu River Estuary, southern China: Pore water profiles and sediment incubations revealed benthic early diagenesis as well as sediment-water exchange of dissolved nutrients and oxygen, while tidal sampling of estuarine and mangrove water identified source and sink functions of the entire mangrove forest. Fluxes of oxygen during incubations were always directed into the sediment, indicating heterotrophy of the system. There was a net uptake of dissolved inorganic nitrogen, mainly caused by nitrate influx, while ammonium and nitrite showed variable flux direction. Despite high pore water concentrations, phosphate and silica showed net uptake. Fluxes of dissolved
\end{abstract}


organic carbon were generally low except for high efflux in the dark following a storm event. Due to the combination of small forest area and strong anthropogenic nutrient input, the net sink function for dissolved nitrogen and phosphorus provides no significant buffer against the eutrophication of coastal waters.

Keywords: benthic nutrient fluxes; early diagenesis; South China Sea; filtration capacity; storm impact; sediment core incubation; mangroves

\section{Introduction}

Coastal ecosystems are under increasing stress from anthropogenic eutrophication. Enhanced land-ocean fluxes of dissolved nutrients can lead to phytoplankton community shifts and production increase, causing higher frequency of harmful algal blooms, and hypoxia and anoxia, with dramatic loss in benthic and pelagic biodiversity and a spread in so-called "dead zones" [1-8]. These problems are particularly severe in the tropics and subtropics (e.g., $[9,10])$ because many coastal ecosystems, like coral reefs and many seagrass areas, are particularly adapted to oligotrophic conditions and sensitive to nutrient pollution. In addition, human activity currently increases nutrient pollution more in developing countries in subtropical and tropical areas than in developed countries in higher latitudes, where nutrient management has evolved further. Despite this, low latitude regions are underrepresented in scientific research [11].

Mangroves covered nearly $167,000 \mathrm{~km}^{2}$ in tropical and subtropical coastal regions at the beginning of the 21 st century [12]. Growing agriculture, aquaculture, and urban development led to widespread mangrove degradation. Global loss rates are about $1 \%$ per year and the total global mangrove area has been reduced by $35 \%$ since the 1980 s (reviewed by [13]). More dramatically, in China, this number is close to $75 \%[12,14]$. This resulted in the loss of essential ecosystem services, including the filtration of anthropogenic pollutants. Mangroves mediate the land-ocean transport of nutrients [15] and may protect adjoining systems from eutrophication [16-18] caused by domestic sewage ([19,20] and references therein), shrimp effluents [21,22], and livestock and industrial waste [23,24]. This pivotal importance in controlling coastal eutrophication and related consequences demands intensified mangrove conservation [16].

Benthic respiration and nutrient regeneration are essential processes in coastal and estuarine ecosystems, controlling organic carbon cycling and the flux of nutrient-type elements across the sediment-water interface [25-27]. In mangrove forests, rates of nutrient conversion, uptake, removal, and immobilization by benthic sedimentary processes can be higher than by than mangrove vegetation [28]. Pore water profiles of dissolved species can be used to estimate diffusive benthic fluxes relating to the concentration gradients that result from microbial activity in the sediment [29]. However, benthic macrofauna alter actual fluxes compared to diffusive transport through bioturbation, advection, and foraging activity [30-34]. Fluxes are further affected by uptake and release of nutrients by microphytobenthos and other microorganisms at the sediment surface [35-37]. Intact sediment core incubations yield reliable results of actual fluxes [38], and have been used in different environmental systems, including lakes (e.g., [39]), estuaries [40], coastal seas [41], and the deep sea [42]. Despite some criticism of the application of laboratory experiments [43], other studies found no differences between in situ and ex situ incubations [44]. Recent studies investigated total mangrove system sink and source 
function by comparing concentration differences between flood and ebb waters [16,45-48], rather than focusing on pore waters or interface exchange. In this study we combine these approaches to answer questions about (1) the total forest function; (2) the importance of sediment-water-fluxes; and (3) the underlying benthic processes in a south Chinese estuarine mangrove system.

The Nanliu River Estuary receives very high inputs of anthropogenic nutrients, bearing the potential for eutrophication of adjacent coastal waters [49,50]. Aquaculture development has led to the loss of mangroves as natural filtration systems, with an area reduction from 1790 ha to 515 ha between the early 1990s and 2011 [14]. Furthermore, as is typical for coastal areas, the region is characterized by rapid population growth. Aiming to uncover the sink and source function of these mangroves and their filtration service, we found no substantial filtration of overwhelming anthropogenic inputs, despite net uptake of eutrophication-critical nutrients.

\section{Materials and Methods}

\subsection{Study Site}

The Nanliu River Estuary, Guangxi, southern China (Figure 1) receives strong anthropogenic nutrient inputs from agriculture and brackish water shrimp ponds [50] (compare Table 3 in Section 4.3).

Mangroves are dominated by a dwarf growth form of Aegiceras corniculatum, intermixed with patches of Kandelia candel, and occupy 515 ha of the intertidal zone. Narrow bands fringe the river banks up to $7 \mathrm{~km}$ upstream, while larger mangrove areas form islands within the river mouth. Mostly diurnal macro tides of up to $4.5 \mathrm{~m}$ induce long desiccation times of on average $18 \mathrm{~h}$ daily. Individual mangrove islands are relatively small plateaus with steep banks. Consequently, strong tidal currents cause a uniform inundation of the mangrove forest. The current mangrove area was inferred from satellite images, in which mangroves were overlaid with digital paint, the area of which was calculated using ImageJ software (version 1.44).

The coastal area of Guangxi is influenced by the East Asian monsoon, with cool, dry winters and springs and warm, wet summers and autumns. Typhoons and tropical storms affect the region on average five times a year [49]. During this study, the tropical storm Nesat passed the coast on 1 October 2011, causing the year's highest daily precipitation and increased suspended sediment transport in the river for several days [51].

\subsection{Field Sampling}

Water from an estuarine mangrove channel was sampled hourly for $24 \mathrm{~h}$ over spring and neap tidal cycles in March and September 2011. Neap tide data from March is not shown as high tide did not inundate mangrove sediments. High tide samples reflect the composition of water entering the mangroves. Effluents leaving the mangroves were sampled hourly from a small nearby high intertidal creek during low tides (Figure 1). Water was analyzed in situ for temperature and salinity using Hach Lange sensors and probes (Hach Lange GmbH, Berlin, Germany). Aliquots for measurements of dissolved inorganic nutrients and dissolved organic carbon (DOC) were filtered immediately through mixed ester cellulose syringe pre-filters into pre-rinsed HDPE bottles and combusted glass containers and fixed with mercury chloride and phosphoric acid, respectively. Samples were stored on ice during field excursions and frozen in the 
laboratory until analysis within 10 weeks at the Leibniz Center for Tropical Marine Ecology (ZMT) in Bremen, Germany.

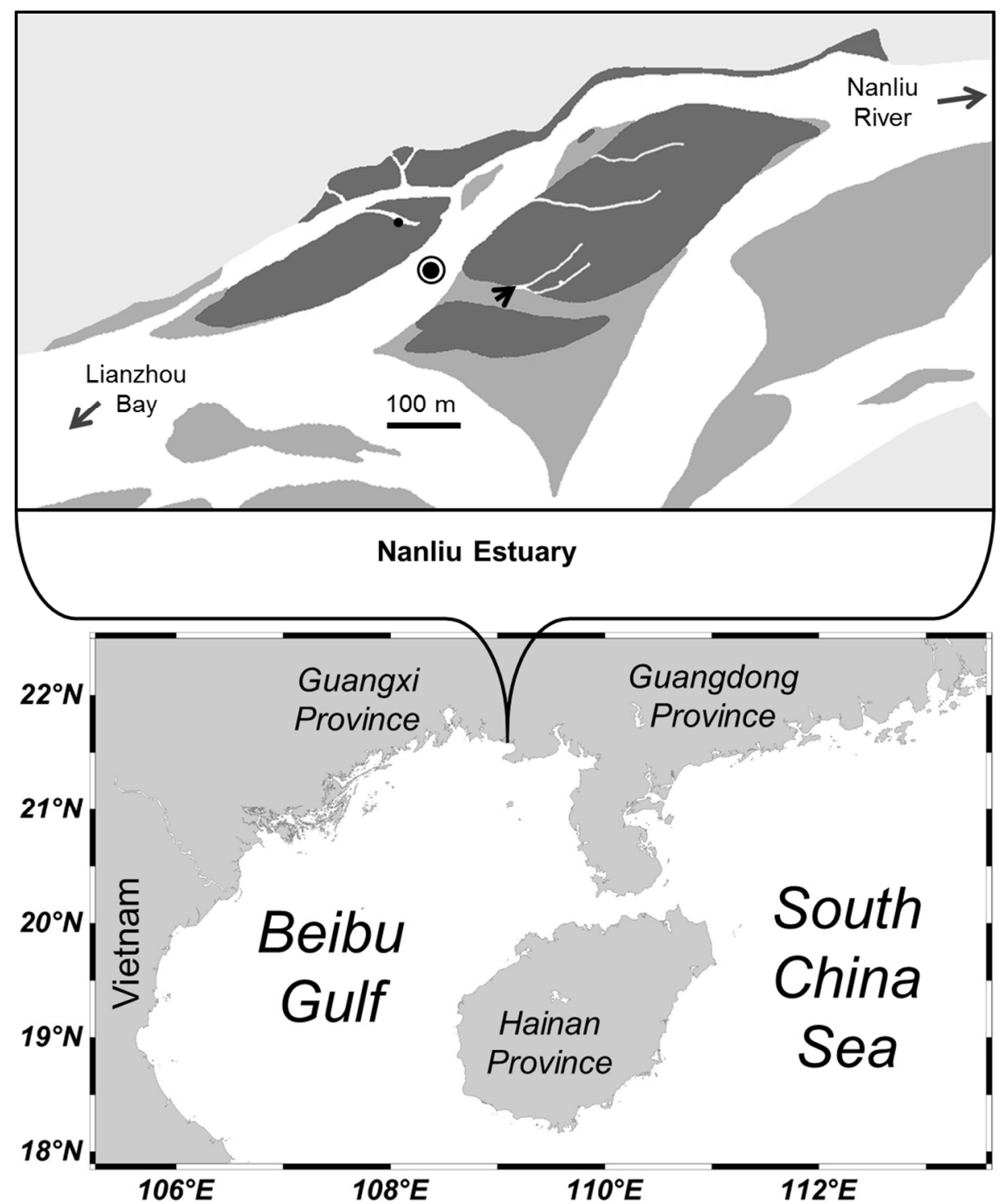

Figure 1. Studied mangrove site in the Nanliu River Estuary. Dark gray areas are mangrove forest, medium gray areas are low intertidal sand banks, the small black dot shows the sediment core sampling site, the concentric symbol shows the tidal sampling site $\left(21^{\circ} 37^{\prime} 6.85^{\prime \prime} \mathrm{N}, 109^{\circ} 1^{\prime} 40.15^{\prime \prime} \mathrm{E}\right)$, and a small black arrow indicates the mangrove effluent sampling site. Up- and downriver directions are indicated by black arrows. For a more detailed map of the estuary see [50].

Sediment cores were sampled using $70 \mathrm{~cm}$ long transparent Plexiglas liners with an internal diameter of $72 \mathrm{~mm}$ (Hydrobios, Kiel, Germany). Within a large mangrove patch, cores were taken from the edge of the forest near a high intertidal creek (Figure 1). Replicate cores were taken within an area of no more than $10 \mathrm{~m}^{2}$. During sampling we took care to keep an undisturbed, horizontal sediment surface. Cores were sectioned after use and slices were macroscopically examined. No cores contained macrofauna or roots. Thus, the effect of bioturbation is excluded in this study. 
Cores for the extraction of pore water were sampled in triplicate on 3 March and 22 September 2011. On 3 October 2011, after the tropical storm Nesat, one additional core was taken. The coefficient of variability of triplicate pore water concentrations of all nutrients was generally low $(<0.2)$ at any given sediment depth, indicating that one core can be regarded as representative. Immediately after sampling and removal of overlying water, pore water was extracted in $2 \mathrm{~cm}$ intervals through pre-drilled holes using Rhizones ${ }^{\circledR}$ (Rhizosphere, Wageningen, The Netherlands) attached to clean syringes. No more than 2-5 mL were extracted from each sediment depth, of which $c a$. $1.5 \mathrm{~mL}$ were transferred to $2 \mathrm{~mL}$ incubation vials. Samples for the analysis of phosphate, sulfate, and silica were acidified with concentrated hydrochloric acid to approximately $1 \%$ and stored at $4{ }^{\circ} \mathrm{C}$; those for analysis of nitrate, nitrite, and ammonium were stored frozen.

For sediment incubation six cores were taken on 16 March and 3 October 2011. Overlying water was removed to avoid sediment resuspension and cores were transported to the lab within $2 \mathrm{~h}$.

\subsection{Core Incubation Experiment}

All cores were pre-incubated with $50 \mathrm{~mL}$ of filtered brackish estuarine water for about $1 \mathrm{~h}$ to ensure water saturation of the pore space. Two and four core replicates, respectively, were used for the measurement of dissolved oxygen (DO) and nutrient fluxes. Two empty core liners served as control incubations. For DO measurements cores were adjusted to a headspace of about $500 \mathrm{~mL}$ in the liners, completely filled with filtered $(\mathrm{GF} / \mathrm{F}, 0.45 \mu \mathrm{m})$ estuarine water and sealed without disturbance of the sediment surface. The sealing caps had holes to accommodate a LDO dissolved oxygen sensor (Hach-Lange, Berlin, Germany). Measurements of DO concentration and saturation, and water temperature were done half hourly. For nutrient measurement $500 \mathrm{~mL}$ of filtered estuarine water were added and cores were covered to prevent evaporation. Water samples were drawn hourly through a sampling port in the cover cap. Using this port, the extracted volume was replaced with demineralized water to maintain the incubated volume. To prevent stratification of the water column, incubated water in all cores was permanently circulated using a peristaltic pump. A pump rate of 2 to $2.5 \mathrm{~L} \cdot \mathrm{h}^{-1}$ was chosen to ensure complete circulation of the volume between samplings, while preserving an undisturbed sediment surface. The incubation lasted for eight hours under constant light and temperature conditions. Ambient temperature was chosen according to average seasonal air temperature to be $16{ }^{\circ} \mathrm{C}$ in March and $25{ }^{\circ} \mathrm{C}$ in October (Table 1). Throughout the incubation, the water temperature remained nearly constant, with maximum standard deviations of $0.7{ }^{\circ} \mathrm{C}$ in March and $0.4{ }^{\circ} \mathrm{C}$ in October. Following incubation in the light the overlying water was replaced, and the cores were reused for dark incubation.

Table 1. Initial concentrations of dissolved nutrients and oxygen at the beginning of the incubation experiment, as well as monthly average ambient air temperature and air temperature during incubation.

\begin{tabular}{|c|c|c|c|c|c|c|c|c|c|}
\hline \multirow[b]{2}{*}{ Date } & \multicolumn{7}{|c|}{ Initial Concentrations $[\mu \mathrm{M}]$} & \multicolumn{2}{|c|}{ Temperature $\left[{ }^{\circ} \mathrm{C}\right]$} \\
\hline & $\mathrm{NO}_{3}^{-}$ & $\mathrm{NO}_{2}^{-}$ & $\mathbf{N H}_{4}^{+}$ & $\mathrm{PO}_{4}{ }^{3-}$ & Si & DOC & $\mathbf{O}_{2}$ & $\begin{array}{l}\text { Monthly } \\
\text { Average }\end{array}$ & $\begin{array}{c}\text { During } \\
\text { Incubation }\end{array}$ \\
\hline 16 March 2011 & 197.0 & 5.4 & 9.0 & 2.8 & 76.5 & 383.0 & 308.5 & 15.3 & 16.0 \\
\hline 3 October 2011 & 84.9 & 4.3 & 19.1 & 1.5 & 94.2 & 371.5 & 223.1 & 25.6 & 25.0 \\
\hline
\end{tabular}


Fluxes of dissolved oxygen and nutrients in individual incubation cores were calculated by linear regression of concentration (corrected for dilution) over time (nine times: initial concentrations plus eight hourly samples). Outliers were removed from the regression according to the method by Mortazavi et al. [52]; out of a total of 1323 data pairs, 22 were removed. In no case did the removal change the significance of correlations. Hourly fluxes are equal to the slope of the outlier-free regression line if linear correlation was significant $(p \leq 0.05)$; otherwise net fluxes are defined as zero. Total sediment nutrient fluxes were calculated as the difference of averages in sediment incubations and controls. Statistical comparison of sediment treatment and control fluxes revealed low power (alpha) of $t$-tests due to small sample size. Where alpha was high enough to yield reliable results, treatment and control fluxes were significantly different at $p<0.05$. Negative values represent influxes, positive ones represent effluxes. Dissolved inorganic nitrogen (DIN) fluxes were calculated as sum of nitrate $\left(\mathrm{NO}_{3}{ }^{-}\right)$, nitrite $\left(\mathrm{NO}_{2}^{-}\right)$and ammonium $\left(\mathrm{NH}_{4}^{+}\right)$sediment fluxes.

\subsection{Sample Analysis}

Dissolved inorganic nutrients in water from tidal sampling and mangrove effluents, as well as in incubation samples, were determined with an autoanalyzer (Skalar, San System, Breda, The Netherlands). Measurements for $\mathrm{NO}_{3}{ }^{-}, \mathrm{NO}_{2}{ }^{-}$, phosphate $\left(\mathrm{PO}_{4}{ }^{3-}\right)$, and silica $(\mathrm{Si})$ were done spectrophotometrically following Grasshoff et al. [53], while $\mathrm{NH}_{4}^{+}$was determined fluorometrically following Kérouel and Aminot [54]. DOC was analyzed by chemoluminescence after platinum catalyzed combustion at $720{ }^{\circ} \mathrm{C}$ in a Shimadzu TOC-VCPH (Shimadzu Corp., Kyoto, Japan).

In pore water samples, $\mathrm{PO}_{4}{ }^{3-}, \mathrm{Si}$, sulfate $\left(\mathrm{SO}_{4}{ }^{2-}\right)$, and sodium $\left(\mathrm{Na}^{+}\right)$were measured by ICP-OES (Thermo, iCAP 6300 Duo, Waltham, MA, USA) using 3- and 5-fold dilutions. Measurements were validated with the certified seawater reference standard CASS-5 (National Research Council of Canada, Ottawa, Canada). A spike solution was added to the reference standard as pore water concentrations of $\mathrm{PO}_{4}{ }^{3-}$ and $\mathrm{Si}$ are distinctly higher in the mangrove samples than in the reference material $\left(\mathrm{PO}_{4}{ }^{3-}\right.$ : accuracy: 0.3\%, precision: $1.2 \%$; Si: $1.4 \%, 1.9 \%$; $\mathrm{SO}_{4}{ }^{2-}: 2.7 \%, 1.9 \%$; $\left.\mathrm{Na}^{+}: 0.9 \%, 3.1 \%\right) . \mathrm{NH}_{4}{ }^{+}, \mathrm{NO}_{3}{ }^{-}+$ $\mathrm{NO}_{2}{ }^{-}$, and $\mathrm{NO}_{2}{ }^{-}$were determined by auto analyzer (Seal Analytical, QuAAtro, Southampton, $\mathrm{UK}$ ). $\mathrm{NO}_{3}{ }^{-}$ was calculated as difference between $\mathrm{NO}_{3}{ }^{-}+\mathrm{NO}_{2}{ }^{-}$and $\mathrm{NO}_{2}{ }^{-}$. A multi-ion standard solution (Bernd Kraft $\mathrm{GmbH}$, Duisburg, Germany) was used for quality control $\left(\mathrm{NH}_{4}^{+}\right.$: accuracy: $8.5 \%$, precision: $8.7 \%$; $\left.\mathrm{NO}_{3}{ }^{-}+\mathrm{NO}_{2}{ }^{-}: 5.8 \%, 4.6 \%, \mathrm{NO}_{2}{ }^{-}: 4.1 \%, 5.0 \%\right)$.

\section{Results}

\subsection{Concentration Differences between Estuarine Water and Mangrove Effluents}

Nutrient concentrations in the estuarine channel varied strongly at low salinities during low tides (Figure 2). At salinities $>10, \mathrm{NO}_{3}{ }^{-}, \mathrm{NO}_{2}{ }^{-}$, and $\mathrm{Si}$ showed near conservative behavior. The same was true for $\mathrm{NH}_{4}{ }^{+}$and $\mathrm{PO}_{4}{ }^{3-}$ during spring tides, while neap tide showed highly variable concentrations.

Concentrations in mangrove effluents mostly deviated positively $\left(\mathrm{NH}_{4}{ }^{+}, \mathrm{Si}\right)$ or negatively $\left(\mathrm{NO}_{3}{ }^{-}\right.$, $\mathrm{NO}_{2}{ }^{-}, \mathrm{PO}_{4}{ }^{3-}$ ) from those expected from mixing of riverine and marine endmembers (Figure 2). Compared to inundating marine waters, mangrove effluents had higher concentrations of $\mathrm{NH}_{4}^{+}, \mathrm{Si}$, and DOC, but lower concentrations of $\mathrm{NO}_{3}{ }^{-}, \mathrm{NO}_{2}{ }^{-}$, and $\mathrm{PO}_{4}{ }^{3-}$ (Figure 2). During spring tides, lower salinity 
in effluents than high tide samples indicated influence of freshwater from the river. This cannot explain the decrease of $\mathrm{NO}_{3}{ }^{-}, \mathrm{NO}_{2}{ }^{-}$, and $\mathrm{PO}_{4}{ }^{3-}$, since concentrations of all nutrients are higher in riverine than marine water [50]. In September, concentrations of $\mathrm{Si}$ and $\mathrm{NH}_{4}{ }^{+}$were higher in effluents than in riverine water, indicating a source within the mangrove.
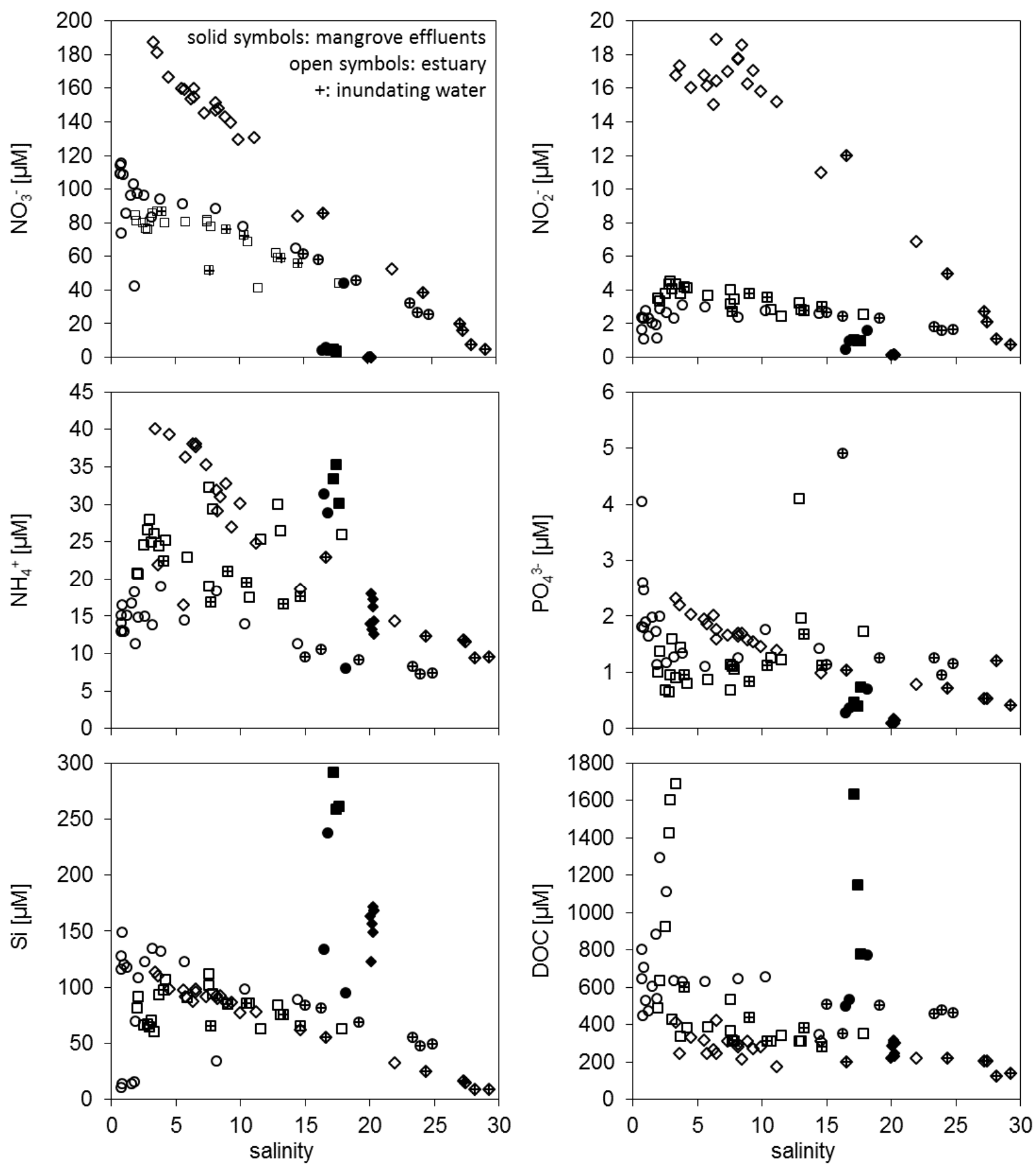

Figure 2. Concentrations of dissolved inorganic nutrients and dissolved organic carbon (DOC) from $24 \mathrm{~h}$ estuarine tidal cycles (open symbols) and from mangrove effluents (solid symbols) plotted against salinity. Diamonds are from spring tide of March 2011, while circles and squares are from spring and neap tides of September 2011, respectively. Values of high tide samples inundating mangrove sediments are marked + . 


\subsection{Mangrove Sediment Pore Water Profiles}

Pore water concentrations of $\mathrm{NO}_{3}{ }^{-}$decreased quickly within the first centimeters while $\mathrm{NH}_{4}{ }^{+}, \mathrm{PO}_{4}{ }^{3-}$, and $\mathrm{Si}$ increased with sediment depth (Figure 3a-c). Depth integrated concentrations of $\mathrm{Si}$ and $\mathrm{NO}_{3}{ }^{-}$ were significantly lower in March (Figure 3a) than in September (Figure 3b) ( $t$ and $U$ tests). In March, $\mathrm{PO}_{4}{ }^{3-}$ and $\mathrm{Si}$ concentrations were low in the top $5 \mathrm{~cm}$ of the sediment, then increased strongly towards a sediment depth of about $8 \mathrm{~cm}$, where the gradient decreased considerably. After the tropical storm in October, surface sediment $\mathrm{NO}_{3}{ }^{-}$and $\mathrm{NO}_{2}{ }^{-}$concentrations were distinctly higher (Figure $3 \mathrm{c}$ ) compared to regular summer profiles (Figure $3 \mathrm{~b}$ ). Concentrations of $\mathrm{NH}_{4}{ }^{+}$remained low in the top $10 \mathrm{~cm}$, showing just a slight increase below $15 \mathrm{~cm}$ sediment depth (Figure 3c).
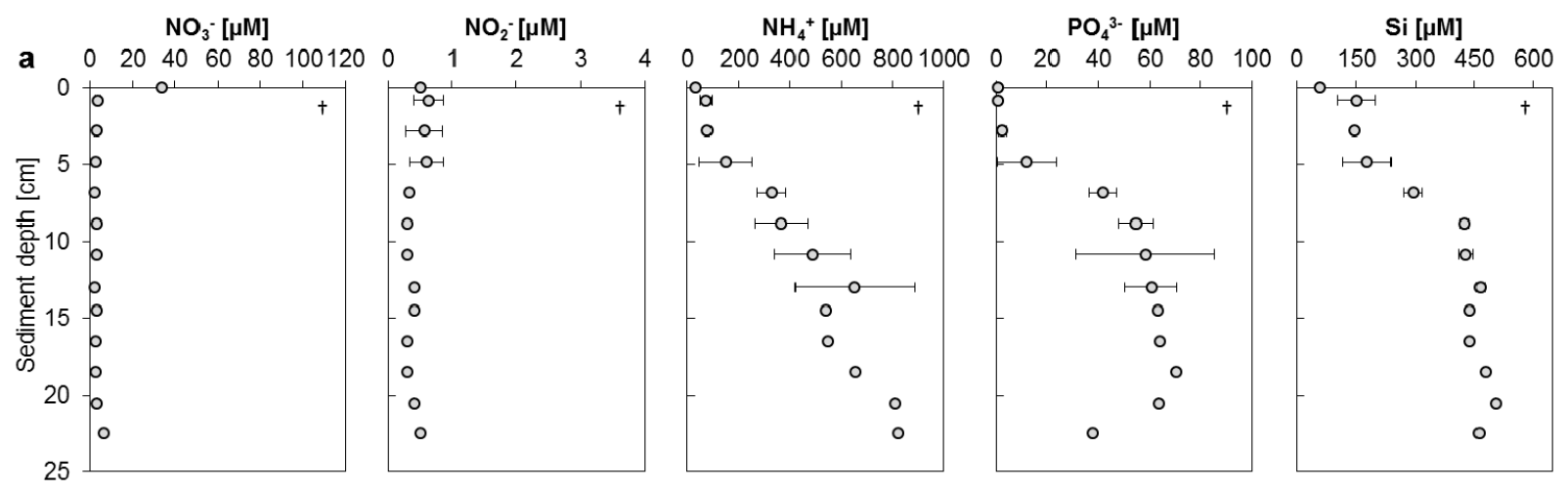

b $\quad 0 \quad 20 \quad 40 \quad 6080100120$
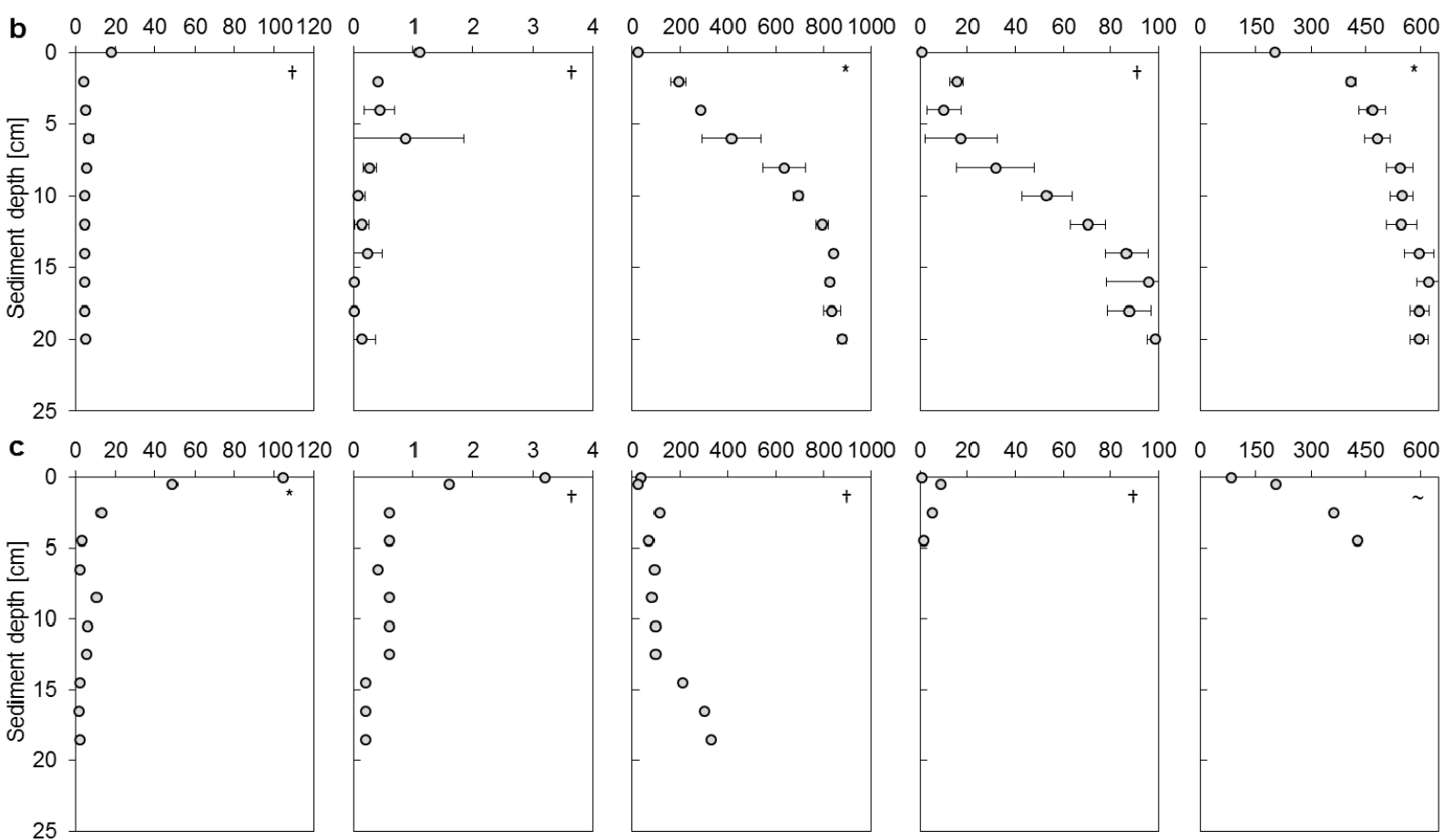

Figure 3. Pore water nutrient concentration profiles of mangrove sediment cores during spring (March) (a); regular summer (September) (b); and post-storm conditions in October (c). In (c) no data is available for $\mathrm{PO}_{4}{ }^{3-}$ and Si below $5 \mathrm{~cm}$ sediment depth. Significantly different concentrations in surface sediments between samplings are marked by different symbols in the top right corner of panels ( $<0 \mathrm{~cm},>5 \mathrm{~cm}$; one-way ANOVA, $p<0.05)$. 
Figure 4 shows the net $\mathrm{SO}_{4}{ }^{2-}$ reduction as the difference between $\mathrm{SO}_{4}{ }^{2-}$ concentrations measured in pore water and calculated from profiles of sodium $\left(\mathrm{Na}^{+}\right)$as a conservative indicator for salinity. Net $\mathrm{SO}_{4}{ }^{2-}$ reduction occurred in March and September. Depth integrated average reduction (2.9 vs. $4.2 \mathrm{mM}$ ) was higher in September. The difference was not statistically significant ( $t$-test, $p>0.05)$, however, and maximum values occurred at sediment depth in March. $\mathrm{No} \mathrm{SO}_{4}{ }^{2-}$ reduction was apparent in post-storm surface sediments (Figure 4c). Low $\mathrm{SO}_{4}{ }^{2-}$ concentrations in surface sediments also reflect the increased influence of freshwater from typhoon-enhanced river discharge compared to regular summer conditions (Figure 4b).
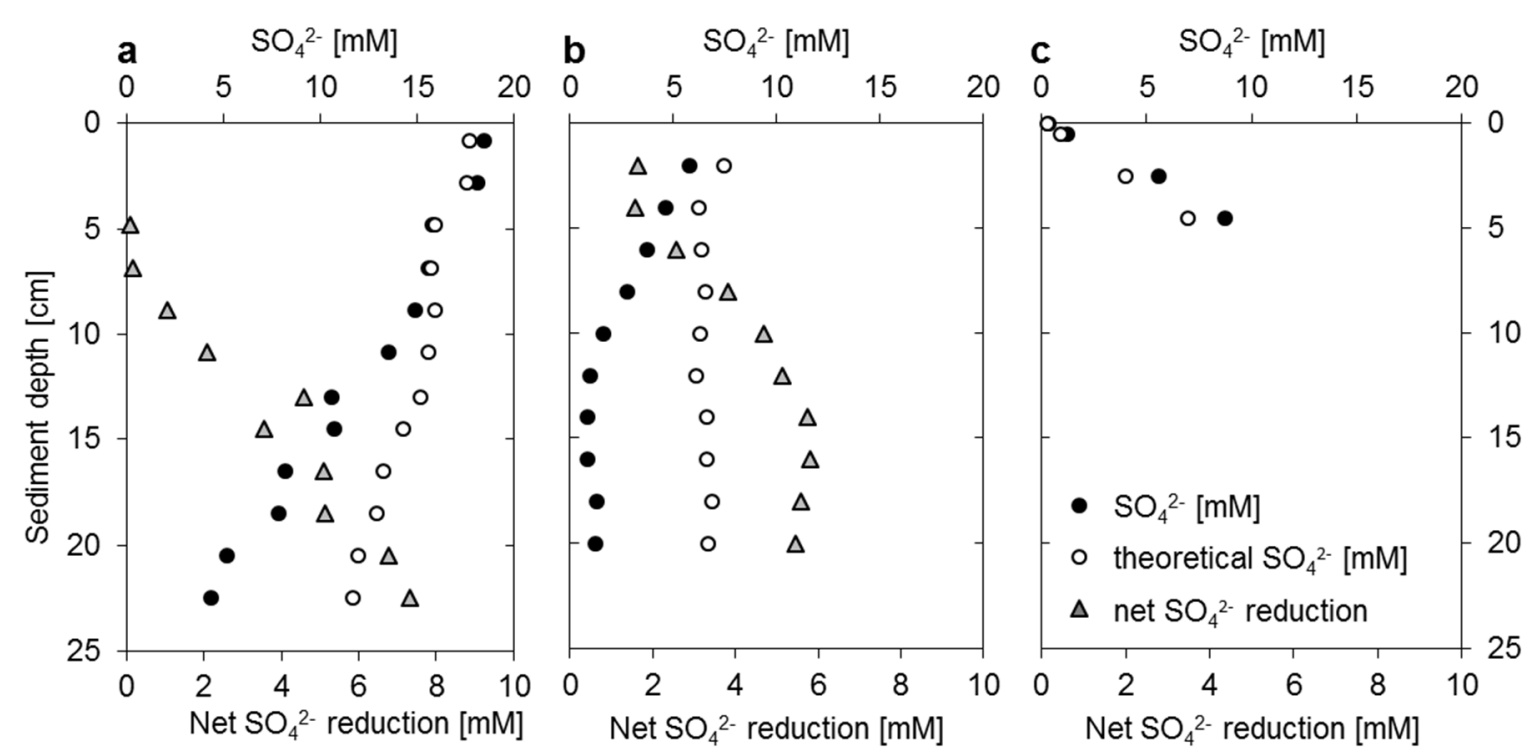

Figure 4. Pore water profiles of measured (black dots) and salinity-based (open dots) $\mathrm{SO}_{4}{ }^{2-}$ concentrations and net $\mathrm{SO}_{4}{ }^{2-}$ reduction (gray triangles) in March (a); regular summer in September (b); and post-storm conditions in October (c).

\subsection{Mangrove Sediment-Water Fluxes}

Table 1 shows the dissolved nutrient concentrations of water used in the intact core incubation experiment. Concentrations of dissolved oxygen were higher in March, and despite the higher oxygen solubility at lower water temperature caused higher DO saturation (96.4\%) compared to October $(89.9 \%)$.

\subsubsection{Dissolved Oxygen}

Dissolved oxygen fluxes were always directed into the sediment and stronger in the dark than in the light. In our calculations we assume that respiration (Resp) equals measured dark fluxes (oxygen removal without simultaneous production), net primary production (NPP - the sum of photosynthetic oxygen production and oxygen removal) equals measured light fluxes, and gross primary production (GPP - photosynthetic oxygen production) is calculated as their difference (Figure 5). Respiration, net primary production, and gross primary production were stronger in March than October. The ratio of GPP to respiration (P:R) changed from -0.13 in March to -0.22 in October (Figure $5 b$ ). 
Applying a respiratory quotient (RQ; $\mathrm{CO}_{2}$ release/ $\mathrm{O}_{2}$ uptake) of 1 [55-57], aerobic respiration caused a carbon oxidation of $752 \mu \mathrm{molC} \cdot \mathrm{m}^{-2} \cdot \mathrm{h}^{-1}$ and $669 \mu \mathrm{molC} \cdot \mathrm{m}^{-2} \cdot \mathrm{h}^{-1}$, while GPP fixed $193 \mu \mathrm{molC} \cdot \mathrm{m}^{-2} \cdot \mathrm{h}^{-1}$ and $248 \mu \mathrm{molC} \cdot \mathrm{m}^{-2} \cdot \mathrm{h}^{-1}$ in March and October, respectively. Considering 12 daylight hours in March and $14 \mathrm{~h}$ in October for GPP, these rates resulted in a net efflux of $\mathrm{CO}_{2}$ from the sediment of $15,724 \mu \mathrm{molC} \cdot \mathrm{m}^{-2} \cdot$ day $^{-1}$ and $12,583 \mu \mathrm{molC} \cdot \mathrm{m}^{-2} \cdot \mathrm{day}^{-1}$, respectively. Based on the calculated carbon uptake during GPP and a $\mathrm{C}: \mathrm{N}$ ratio of 10 for microphytobenthos (see [36]), the nitrogen demand for primary production was $231 \mu \mathrm{molN} \cdot \mathrm{m}^{-2} \cdot \mathrm{day}^{-1}$ and $348 \mu \mathrm{molN} \cdot \mathrm{m}^{-2} \cdot$ day $^{-1}$ during March and October, respectively (Table 2a). It should be noted that RQ and C:N may vary in time and space and these calculations are first order estimates.
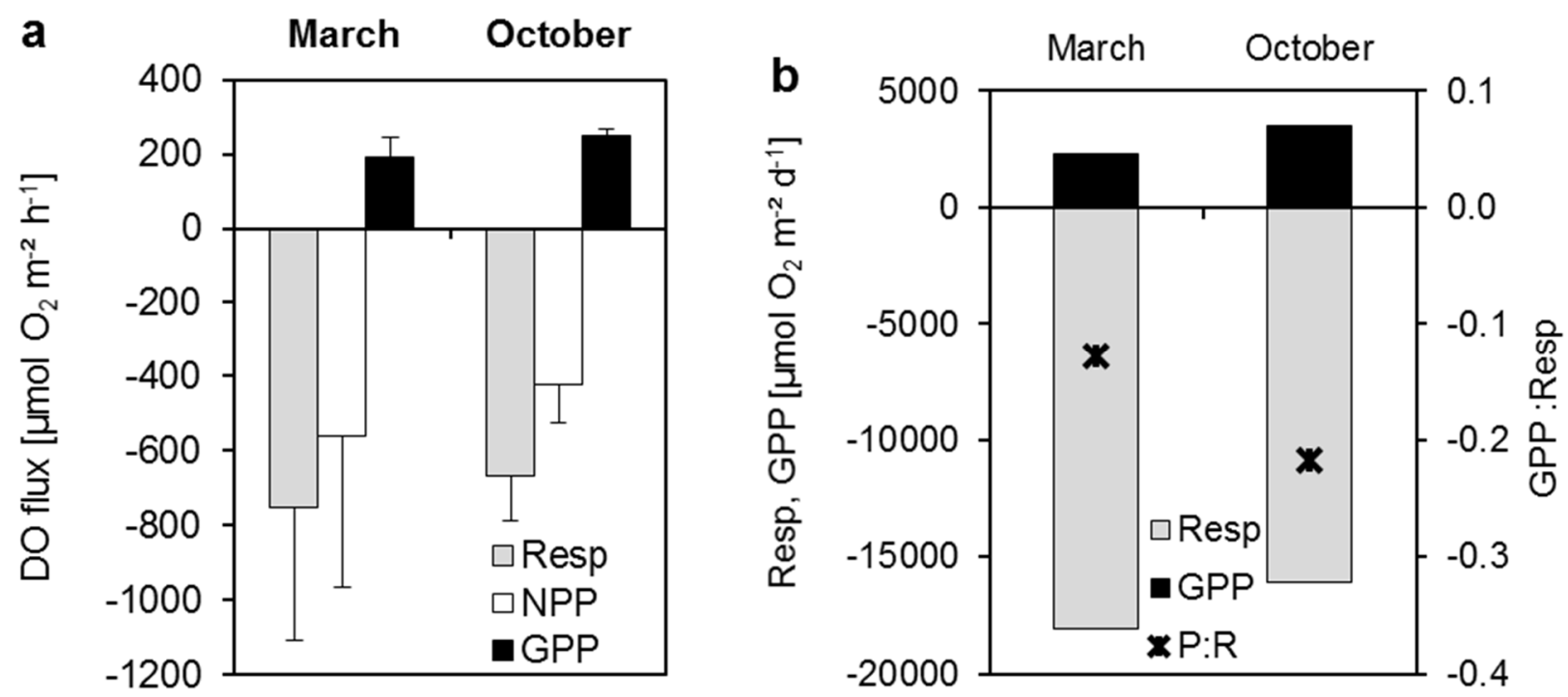

Figure 5. Hourly (a) and diel (b) total fluxes of dissolved oxygen. Respiration (Resp) equals measured dark fluxes, net primary production (NPP) equals measured light fluxes, and gross primary production (GPP) is calculated as their difference. Panel (b) also shows the ratio of GPP to respiration (P:R).

\subsubsection{Dissolved Nutrient and Organic Carbon Fluxes}

Fluxes of dissolved inorganic nitrogen (DIN) were always directed into the sediment (Figure 6). Uptake was stronger during dark conditions, while diel fluxes were comparable in March and October. Flux directions of individual DIN species were equal during light and dark incubations. In $\mathrm{March}_{2} \mathrm{NO}_{3}{ }^{-}$ showed influx, while $\mathrm{NO}_{2}{ }^{-}$and $\mathrm{NH}_{4}{ }^{+}$were released from the sediment. $\mathrm{NO}_{3}{ }^{-}$influx was lower in October and influx of DIN was maintained by uptake of $\mathrm{NH}_{4}{ }^{+}$and $\mathrm{NO}_{2}{ }^{-}$. Uptake of dissolved Si occurred during light conditions and was stronger in October. No net flux was detected in the dark. In March, $\mathrm{PO}_{4}{ }^{3-}$ fluxes were directed into the sediment. Higher light influx in October was balanced by dark efflux to result in similar diel $\mathrm{PO}_{4}{ }^{3-}$ uptake as in March. Dissolved organic carbon (DOC) was generally taken up by the sediment, except for a strong release during the dark in October, which resulted in a net diel efflux. 
Table 2. Hourly and diel benthic fluxes. (a) Respiration, NPP, and GPP (all in $\mu$ mol $\mathrm{O}_{2}$ ), as well as calculated $\mathrm{CO}_{2}$ flux and nitrogen $(\mathrm{N})$ demand, assuming a respiratory quotient (RQ) of 1 and a $\mathrm{C}: \mathrm{N}$ ratio for microphytobenthos of 10, diel fluxes are based on 12 and 14 hours of daylight in March and October, respectively; (b) Nutrient fluxes measured during core incubations. Diel fluxes are based on an inundation time of $6 \mathrm{~h}$ per day.

\begin{tabular}{|c|c|c|c|c|c|c|}
\hline \multirow[b]{2}{*}{$\mathbf{a}$} & \multicolumn{4}{|c|}{ Hourly flux $\left[\mu \mathrm{mol} \mathrm{m}^{-2} \mathrm{~h}^{-1}\right]$} & \multicolumn{2}{|c|}{$\begin{array}{c}\text { Daily flux [ } \mu \mathrm{mol} \mathrm{m} \mathrm{m}^{-2} \\
\left.\mathrm{day}^{-1}\right]\end{array}$} \\
\hline & \multicolumn{2}{|c|}{ Spring } & \multicolumn{2}{|c|}{ Summer } & Spring & Summer \\
\hline Respiration & \multicolumn{2}{|c|}{-499.4} & \multicolumn{2}{|c|}{-669.3} & -11985.1 & -16062.2 \\
\hline NPP & \multicolumn{2}{|c|}{-270.5} & \multicolumn{2}{|c|}{-420.8} & -9238.4 & -12583.2 \\
\hline GPP & \multicolumn{2}{|c|}{228.9} & \multicolumn{2}{|c|}{248.5} & 2746.7 & 3478.9 \\
\hline $\mathrm{CO}_{2}$ efflux & \multicolumn{2}{|c|}{499.4} & \multicolumn{2}{|c|}{669.3} & 11985.1 & 16062.2 \\
\hline $\mathrm{CO}_{2}$ influx & \multicolumn{2}{|c|}{-228.9} & \multicolumn{2}{|c|}{-248.5} & -2746.7 & -3478.9 \\
\hline $\mathrm{CO}_{2}$ net flux & \multicolumn{2}{|c|}{384.9} & \multicolumn{2}{|c|}{524.3} & 9238.4 & 12583.2 \\
\hline $\mathrm{N}$ demand & \multicolumn{2}{|c|}{22.9} & \multicolumn{2}{|c|}{24.8} & 274.7 & 347.9 \\
\hline \multicolumn{7}{|l|}{ b } \\
\hline $\begin{array}{l}\text { Measured } \\
\text { fluxes }\end{array}$ & Light & Dark & Light & Dark & Diel & Diel \\
\hline $\mathrm{NO}_{3}^{-}$ & -279.1 & -339.6 & -16.3 & -83.9 & -1856.1 & -266.7 \\
\hline $\mathrm{NO}_{2}^{-}$ & 37.0 & 13.1 & 4.5 & -17.1 & 150.4 & -27.1 \\
\hline $\mathrm{NH}_{4}^{+}$ & 28.4 & 85.9 & -104.3 & -251.8 & 342.9 & -994.3 \\
\hline DIN & -213.7 & -240.6 & -116.1 & -352.7 & -1362.7 & -1288.1 \\
\hline $\mathrm{PO}_{4}{ }^{3-}$ & -14.3 & -12.1 & -30.2 & 11.1 & -79.1 & -78.0 \\
\hline $\mathrm{Si}$ & -6.3 & 0.0 & -51.7 & 0.0 & -19.0 & -181.1 \\
\hline DOC & -790.5 & -305.6 & -1518.4 & 3900.7 & -3288.3 & 4437.3 \\
\hline
\end{tabular}

\section{Discussion}

\subsection{Sediment-Dissolved Oxygen Fluxes}

The respiration rates in sediments of the Nanliu mangrove forest are within the range found in similar Asian and Australian mangrove settings [28,55,56,58-65], but are lower than in the mangrove sediments of Central America [66,67]. Oxygen uptake rates are particularly low compared to mangroves of the Jiulongjiang Estuary in China, for which Alongi et al. [68] assumed that rapid sediment accumulation supplies reactive organic matter supporting high respiration rate. Respiration rates observed in the present study may also be low because of lacking bioturbation (e.g., crab burrows) in sampled sediment cores. Oxygen decrease in overlying water has been shown to be higher in areas with burrows compared to undisturbed sediments in the same mangrove [66]. Burrows and roots, furthermore, promote respiration during desiccation [56]. Though differences between inundated and desiccated respiration cannot be generalized $[56,58,64,69]$, the diel rates shown in Figure 5b should be considered minimum fluxes. Rates 
of gross primary production (GPP) are also lower than in other mangrove systems $[59,61]$. This may be due to low microphytobenthos biomass, as GPP and the P:R ratio are similar to those in mangrove systems with low benthic microalgal standing stocks [70].
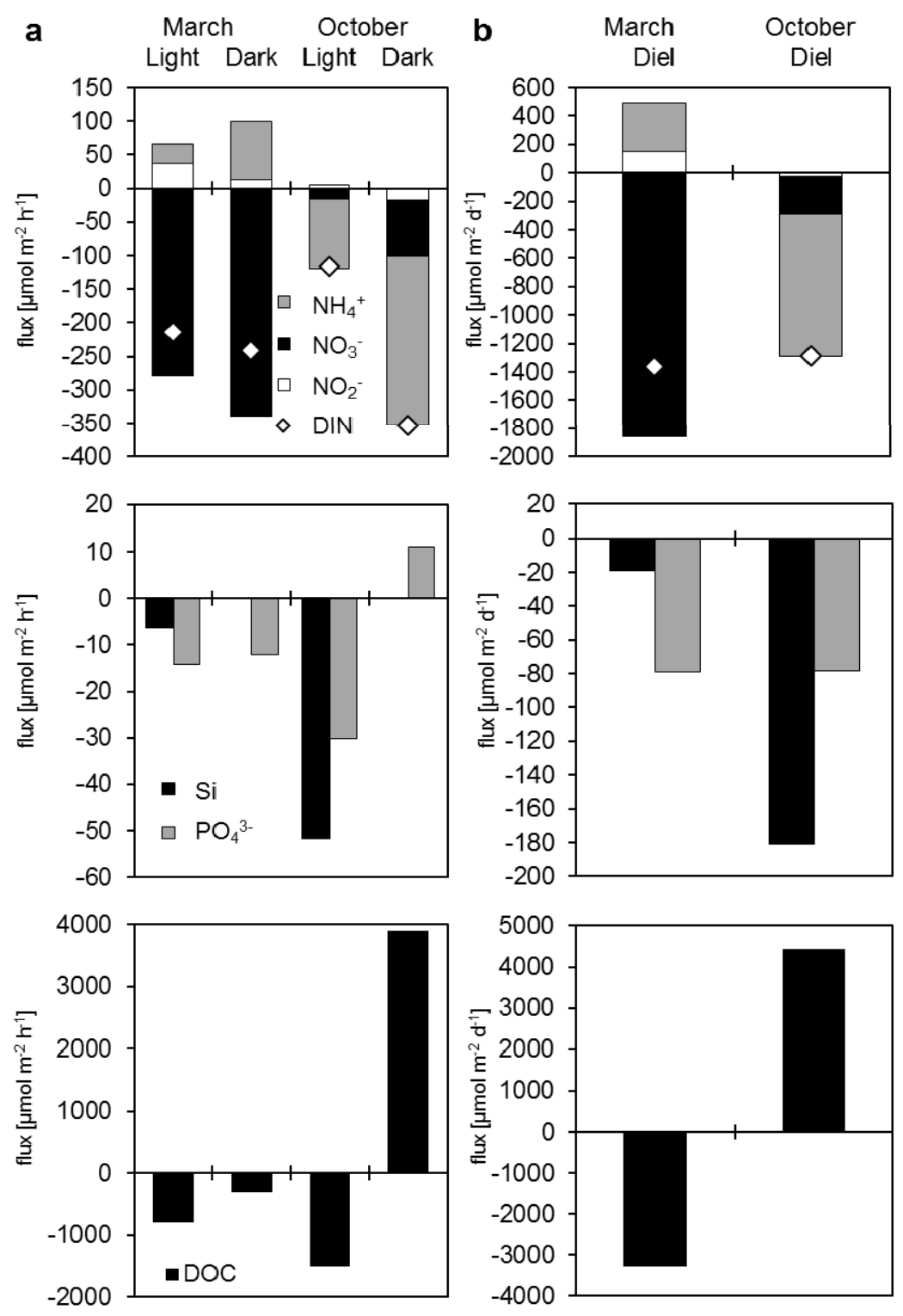

Figure 6. Total sediment fluxes of dissolved nutrients; (a) hourly $\left[\mu \mathrm{mol} \cdot \mathrm{m}^{-2} \cdot \mathrm{h}^{-1}\right]$; and (b) diel $\left[\mu \mathrm{mol} \cdot \mathrm{m}^{-2} \cdot \mathrm{day}^{-1}\right]$. Dissolved inorganic nitrogen (DIN) flux is calculated as the sum of nitrate $\left(\mathrm{NO}_{3}{ }^{-}\right)$, nitrite $\left(\mathrm{NO}_{2}{ }^{-}\right)$, and ammonium $\left(\mathrm{NH}_{4}^{+}\right)$fluxes. Diel fluxes are based on an inundation time of $6 \mathrm{~h}$ per day.

Stronger $\mathrm{O}_{2}$ uptake occurred in March (Figure 5). Generally, increased sediment $\mathrm{O}_{2}$ dynamics and gas fluxes during are expected during warmer seasons [52,60,62,68,70-74], which favor the activity of benthic microorganisms [75-77]. Higher GPP in October indicates that microphytobenthos productivity indeed did increase. Decreased aerobic respiration is likely due to sediment disturbance by the tropical storm Nesat a few days before the experiment. Sediment mobilization by extreme storms ventilates the pore space $[78,79]$, reducing the demand for oxidizing agents. Together with increased GPP, this led to 
lower $\mathrm{O}_{2}$ influx on October. The decreased reductive state of the post-storm sediments is also reflected in nutrient dynamics (Section 4.2).

Constant net uptake of dissolved oxygen in the incubation experiment (Figure 5) shows that the benthic system of these mangroves is always heterotrophic, as is common in mangrove sediments $[56,60,70,72,80]$, which are consequently a net source of carbon dioxide $\left(\mathrm{CO}_{2}\right)$ to the overlying bottom water [72]. $\mathrm{CO}_{2}$ efflux from sediments of the Nanliu mangrove (Table $2 \mathrm{a}$ ) is only about $10 \%-50 \%$ of the $\mathrm{CO}_{2}$ production measured in mangroves and adjacent mudflats in Thailand [58,60,64] and China [68]. Calculated aerobically driven $\mathrm{CO}_{2}$ efflux is amended by anaerobic carbon oxidation, with $\mathrm{SO}_{4}{ }^{2-}$ reduction dominating belowground carbon oxidation in mangroves $[55,64,68,69]$. Net $\mathrm{SO}_{4}{ }^{2-}$ depletion should be exceeded by the actual carbon oxidation with $\mathrm{SO}_{4}{ }^{2-}$ (e.g., [81]). $\mathrm{SO}_{4}{ }^{2-}$ reduction in the Nanliu mangrove (Figure 4) may thus strongly increase $\mathrm{CO}_{2}$ efflux over the values calculated from $\mathrm{O}_{2}$ uptake.

\subsection{Organic Carbon and Nutrient Fluxes}

Dissolved organic carbon (DOC) exhibits the strongest benthic fluxes measured in the Nanliu mangrove forest (Figure 6), but rates are low compared to other mangroves, estuaries, and shallow coastal areas $[82,83]$. The observed temporal variability in benthic DOC flux magnitude and direction is common in mangroves (e.g., [47,60,62]). Despite high pore water concentrations, efflux may cease or even reverse direction due to DOC uptake by bacteria at the sediment surface [70,84,85].

Benthic-dissolved nitrogen fluxes in the Nanliu mangrove forest are within the range measured in other mangrove areas, and show comparatively low temporal variability between March and October $[28,55,58,61-64,68,86]$. Both the incubation experiment (Figure 6) and pore water profiles (Figure 3) show that the sediments are a sink for dissolved nitrogen. Mangrove sediments are generally DIN sinks, mostly due to the uptake of $\mathrm{NO}_{3}{ }^{-}$, while $\mathrm{NH}_{4}{ }^{+}$often shows efflux [60-62,87-91]. Several benthic processes cause the removal of $\mathrm{NO}_{3}{ }^{-}$from overlying water. While assimilation by primary producers removes $\mathrm{NO}_{3}{ }^{-}$[92], it is probably no major $\mathrm{NO}_{3}{ }^{-}$sink as daytime nitrogen removal strongly exceeded GPP-associated nitrogen demand (Table 2), and $\mathrm{NO}_{3}{ }^{-}$uptake was higher in the dark (Figure 6). Pore water profiles from the Nanliu mangrove forest indicate the removal of $\mathrm{NO}_{3}{ }^{-}$by denitrification (compare e.g., [26]), an important sink for $\mathrm{NO}_{3}{ }^{-}$in mangroves (e.g., [93,94]), during which $\mathrm{NO}_{3}{ }^{-}$retains oxidizing conditions when oxygen availability is limited [39]. This reducing process can increase with $\mathrm{NO}_{3}{ }^{-}$availability $[91,95,96]$, but see [72,97]. Since $\mathrm{NO}_{3}{ }^{-}$is the most common form of anthropogenic nitrogen input [98-102], denitrification is particularly important in heavily impacted systems [93] such as the studied mangroves, which receive high loads of $\mathrm{NO}_{3}{ }^{-}$from the Nanliu River [50]. Denitrification can decrease by downward expansion of the oxic layer by photosynthetic oxygen production in light [36], explaining the lower $\mathrm{NO}_{3}{ }^{-}$influx in the light (Figure 6). $\mathrm{NO}_{3}{ }^{-}$can also be utilized in the reoxidation of sulfide [103], produced during $\mathrm{SO}_{4}{ }^{2-}$ reduction (Figure 3), or reoxidation of $\mathrm{NH}_{4}{ }^{+}$at the sediment surface, which introduces $\mathrm{NO}_{3}{ }^{-}$into bottom water. Oxidation with $\mathrm{O}_{2}$ produced during primary production and interception by benthic phytoplankton [36] may be reasons for lower $\mathrm{NH}_{4}^{+}$fluxes during light. The strong increase of $\mathrm{NH}_{4}{ }^{+}$with sediment depth (Figure 3a,b) and its efflux in March suggest $\mathrm{NH}_{4}{ }^{+}$ production concurrent with $\mathrm{NO}_{3}{ }^{-}$removal. Dissimilatory nitrate reduction to ammonium (DNRA) has been proposed as an important and often underestimated $\mathrm{NO}_{3}{ }^{-}$sink [104-106], especially in tropical estuaries with low benthic DO flux rates [107]. In anthropogenically impacted reduced sediments, DNRA may be 
more important than denitrification $[52,108]$. The production of $\mathrm{NH}_{4}{ }^{+}$by DNRA can exceed that by ammonification of organic matter by a factor of 10 [105]. The occurrence of DNRA has important implications for the mangrove because contrary to denitrification it does not remove reactive $\mathrm{N}$ as gaseous $\mathrm{N}_{2}$ but keeps it available in the system as $\mathrm{NH}_{4}^{+}$(e.g., [40]). Both denitrification and DNRA yield $\mathrm{NO}_{2}{ }^{-}$as an intermediate product [40,109-111]. Benthic $\mathrm{NO}_{2}{ }^{-}$fluxes and concentration $>3 \mu \mathrm{M}$ in the incubated water column, as well as measurable pore water concentrations (Figure 3), reflect active DIN conversion processes in the sediment, with $\mathrm{NO}_{2}{ }^{-}$as intermediate product. Strong $\mathrm{NO}_{3}{ }^{-}$reduction in March causes $\mathrm{NO}_{2}{ }^{-}$release into the water column (Figure 6). The efflux does not cause a concentration increase in mangrove effluents (Figure 2) because $\mathrm{NO}_{2}{ }^{-}$undergoes either reoxidation to $\mathrm{NO}_{3}{ }^{-}$or further reduction to $\mathrm{N}_{2}$ in the water column. As the incubation experiment yields net fluxes that are the sum of a combination of processes, specific process-based experiments are desirable to assess their relative importance.

Concentrations of $\mathrm{Si}$ and $\mathrm{PO}_{4}{ }^{3-}$ in pore water generally increase with sediment depth because of the dissolution of siliceous material [26] and remineralization of organic matter [112,113], as well as desorption from particles $[22,114]$. While this creates concentrations gradients between pore water and water column, the flux direction depends on microbial activity at the interface $[26,28,37,55,86]$. In the Nanliu mangrove forest, microphytobenthos abundance and species number are dominated by diatoms [115], which have been suggested to cause Si influx despite high pore water concentrations [116]. Uptake from the pore water pool is indicated by the steepening of the concentration gradient in surface sediments (Figure 3). Utilization by diatoms appears to intercept all diffusive Si efflux in the dark, and increased demand during production in light causes additional uptake from the water column (Figure 6). Influx from the water column is low compared to other studies $[28,55]$, as would be expected from a relatively low GPP.

Though data on benthic $\mathrm{PO}_{4}{ }^{3-}$ fluxes in mangroves are scarce, comparison with earlier results suggests that influxes in the Nanliu mangrove forest are stronger than in other areas $[28,55,86]$. Direct uptake by microorganisms [36] may cause low concentrations in surface sediments, particularly in spring, when supply from deeper sediments is slow compared to regular summer conditions. Lower dark influx in March and dark efflux in October (Figure 6a) are likely due to reduced interceptive uptake of $\mathrm{PO}_{4}{ }^{3-}$ by primary producers in the absence of light. Additional removal of $\mathrm{PO}_{4}{ }^{3-}$ from the water column and pore water might be due to adsorption to iron(III)-oxyhydroxides (e.g., [26]), which is important in removing $\mathrm{PO}_{4}^{3-}$ from pore water and the water column in the study area [117]. Since it is likely that the described processes act simultaneously, process-based experiments are required to show their relative contribution to nutrient dynamics.

Temporal variability in mangrove nutrient dynamics are largely governed by short-term forcing such as light availability [56,118], inundating water nutrient concentrations [45], and precipitation patterns [16,119], while seasonality may generally be weak $[58,88,120]$. Sediment core incubations (Figure 6) and pore water profiles (Figure 3b,c) show that benthic nutrient dynamics, particularly of nitrogen, change fundamentally after a storm event. Following tropical storm Nesat in October, DIN reduction in the surface and subsurface sediment decreased, as seen from the decreases in $\mathrm{NH}_{4}{ }^{+}$accumulation and $\mathrm{NO}_{3}{ }^{-}$ decline (Figure 3b,c), and the reversed flux of $\mathrm{NH}_{4}{ }^{+}$into the sediment (Figure 6). The oxygenation of pore waters during sediment mobilization and ventilation by Nesat probably decreased denitrification [96,121] and enhanced nitrification of $\mathrm{NH}_{4}{ }^{+}$to $\mathrm{NO}_{3}{ }^{-}$[37,59], causing significantly higher $\mathrm{NO}_{3}{ }^{-}$and lower $\mathrm{NH}_{4}{ }^{+}$ concentrations in bottom and surface sediment pore waters (Figure 3c). Due to the deeper penetration of 
$\mathrm{O}_{2}$ and $\mathrm{NO}_{3}{ }^{-}$, the $\mathrm{SO}_{4}{ }^{2-}$ reduction observed in the top $5 \mathrm{~cm}$ during September (Figure $4 \mathrm{~b}$ ) ceased after the storm (Figure 4c). Reducing processes dominate in deeper sediment and $\mathrm{NO}_{3}{ }^{-}$and $\mathrm{NO}_{2}{ }^{-}$are net removed from bottom (Figure 6) and pore waters (Figure 3c). Nevertheless, even days after the storm event, the removal of DIN is dominated by the influx of $\mathrm{NH}_{4}{ }^{+}$. This alternation in nitrogen dynamics through sediment disturbance is important in the Nanliu mangrove, where tropical storms occur on average five times a year. Post-storm profiles of $\mathrm{Si}$ and $\mathrm{PO}_{4}{ }^{3-}$ show significantly decreased concentrations in surface sediments relative to regular summer conditions during September (Figure 3b,c). This is likely due to the loss of nutrients from pore water during storm-induced sediment resuspension [122,123]. The shape of the Si profile does not seem to be affected by the storm event. Since Si is not affected by redox processes to the same degree as DIN, usual profiles may be established quickly after sediment disturbance. Though studies on the effects of extreme storms are rare and difficult to plan due to the stochastic nature of such events, more research is desirable to verify these assumptions.

\subsection{Mangrove System Nutrient Dynamics}

High variability of nutrient concentrations at low salinity and particularly during neap tide shows that at low water levels nutrient composition in estuarine mangrove channels is influenced by effluents and pore water seepage from the mangrove forest. Near-conservative behavior at higher salinity shows that with rising water levels the hydraulic gradient reverses and there is no influx into the channel. Varying concentrations in the estuarine channel and in mangrove effluents during low tide suggest that the influence from the mangrove is temporally variable (Figure 2). During neap tide, salinity was higher in mangrove effluents than inundating water. Increased salinity may be due to evapo-transpiration in the mangrove (see e.g., [47]). This is not evident during spring tides, rather indicating a delayed release of saline water delivered into the mangrove during previous high tides with stronger marine influence (see e.g., [48]).

Deviations of effluent concentrations from those expected from mixing of marine and fresh waters reflect nutrient addition to (positive deviation) or removal from (negative deviation) inundating water during residence time in the mangrove. Since concentrations of all nutrients are higher in riverine than marine water, freshwater influence cannot explain the decrease of $\mathrm{NO}_{3}{ }^{-}, \mathrm{NO}_{2}{ }^{-}$, and $\mathrm{PO}_{4}{ }^{3-}$ in effluents relative to marine inundating water (Figure 2). Extremely low $\mathrm{NO}_{3}{ }^{-}$concentrations in effluents reflect the uptake by sediments. Nevertheless, $\mathrm{NO}_{3}{ }^{-}$concentrations during low tide are similar to those found in the river [50], and display lowest relative variability among nutrient species, indicating that estuarine $\mathrm{NO}_{3}{ }^{-}$dynamics are not significantly influenced by mangroves but are dominated by high riverine inputs. Similarly, DOC concentrations during low tide and in effluents are similar to riverine values (235.3 to $339.6 \mu \mathrm{M}$ and 282.9 to 2345.6 $\mu \mathrm{M}$ in March and September 2011, respectively; Kaiser, unpublished [124]), indicating that despite the benthic uptake of DOC in the mangrove, the influence from the river dominates over mangrove dynamics. Low tide concentrations of $\mathrm{NO}_{2}{ }^{-}$in the estuarine mangrove channel are high compared to effluents and pore water, and are also higher than in Nanliu River. This increase in concentrations despite the dilution by effluents and pore water drainage suggests high rates of in situ nitrogen conversion in the mangrove channel, particularly in March. The dependence of in situ processes, rather than external inputs, was also suggested for $\mathrm{NO}_{2}{ }^{-}$concentrations throughout the estuary [50]. 
Effluent and low tide $\mathrm{Si}$ and $\mathrm{NH}_{4}{ }^{+}$exceed river concentrations [50] and thus cannot solely be sourced from riverine input, but indicate sources within the mangrove which influence estuarine concentrations via effluent runoff and pore water drainage. Increased $\mathrm{NH}_{4}^{+}$values in effluents are due to benthic effluxes (Figures 3a,b and 6) and lateral belowground transport of interstitial water and solutes [47,69]. Lateral transport also increased Si concentrations in effluents (Figure 2) despite measured sediment uptake (Figure 6). An additional possible source of Si to effluents is leaching from macrophytes as well as their epiphytes and debris [125-128]. Deep pore water drainage would also introduce $\mathrm{PO}_{4}{ }^{3-}$, but concentrations are low in effluents compared to channel concentrations (Figure 2). Pore water $\mathrm{PO}_{4}{ }^{3-}$ concentrations only increase strongly below $5 \mathrm{~cm}$ sediment depth, while Si concentrations in the upper $5 \mathrm{~cm}$ are high enough to support high effluent concentrations even during early desiccation and drainage of surface sediment pores. This, together with the shallow depth of small creeks, suggests that lateral drainage into effluents is restricted to the upper sediment layers. Shallow pore water may also be released during sediment resuspension by tidal currents [123].

The pore water profiles (Figure 3a,b) and concentration differences between estuarine water and mangrove effluents (Figure 2) indicate no seasonal alteration in the source and sink function of the mangrove forest or its sediments. Nevertheless, surface sediment pore water concentrations of $\mathrm{NH}_{4}^{+}$, $\mathrm{PO}_{4}{ }^{3-}$, and $\mathrm{Si}$ are significantly higher and accumulate more strongly during summer (September, Figure $3 a, b)$, due to temperature-enhanced remineralization of organic matter [52,129] and leaching from particles [37].

\subsection{Nutrient Filtration by the Mangrove System}

Mangroves have repeatedly been proposed as natural filters for anthropogenic nutrients [21-24,91,130-133]. For DIN and $\mathrm{PO}_{4}{ }^{3-}$, tidal sampling and benthic fluxes indicated similar source and sink functions, highlighting the importance of sedimentary processes (for DIN and $\mathrm{PO}_{4}{ }^{3-}$ dynamics) in the Nanliu mangrove area. Studies have found that sediment biogeochemical processes dominate DIN and $\mathrm{PO}_{4}{ }^{3-}$ removal (e.g., [24]). For these nutrients benthic fluxes may thus be used to estimate the filtration capacity of the mangrove sediment system (Table 3). The main source of nutrients to the estuary and adjacent coastal waters is the $9704 \mathrm{~km}^{2}$ catchment of the Nanliu River, with additional inputs from a 6500 ha aquaculture area [50]. At only 514 ha, the potentially filtering mangrove area is relatively minute. Expanding measured influx rates (Table 2, Figure 6) to the mangrove area, total mangrove $\mathrm{NO}_{3}{ }^{-}$uptake rate may range from -1374 to $-9559 \mathrm{~mol} \cdot \mathrm{d}^{-1}$, while $\mathrm{PO}_{4}{ }^{3-}$ uptake would be between -402 and $-407 \mathrm{~mol} \cdot \mathrm{d}^{-1}$. Consequently, mangroves would remove only $0.1 \%$ to $0.5 \%$ of the $2,013,100 \mathrm{~mol} \cdot \mathrm{d}^{-1} \mathrm{NO}_{3}{ }^{-}$inputs and $1.2 \%$ of the $34,200 \mathrm{~mol} \cdot \mathrm{d}^{-1} \mathrm{PO}_{4}{ }^{3-}$ inputs (Table 3 ). Benthic removal rates must be considered minimum ecosystem filtration service, as other system components, such as mangrove trees, further facilitate uptake of these nutrients.

Low removal capacity has also been shown for an Australian mangrove receiving shrimp aquaculture effluents [65]. In a meta-analysis Valiela and Cole [17] found that the nitrogen removal capacity of wetlands relates negatively to land-derived nitrogen input. The Nanliu estuary has an area of 16,578 ha [134] and annually receives about $10,305 \mathrm{tN}\left(7.7 \times 10^{8} \mathrm{~mol}\right)$ of DIN from the river, 95\% of which is delivered as $\mathrm{NO}_{3}{ }^{-}$[50]. Given this high input of $651.8 \mathrm{kgN} \cdot \mathrm{ha}^{-1} \cdot \mathrm{y}^{-1}$ to the estuary, the low removal by mangrove wetlands of $<1 \%$ land-derived DIN is comparable to other impacted systems [17]. This low filtration 
service suggests that, due to the disadvantageous ratio of mangrove wetland area to land-derived nutrient input, the mangroves do not significantly affect nutrient dynamics in the tidally dominated Nanliu estuary through filtration. These results must be regarded as first estimates, and further studies with wider temporal and spatial resolution would aid the calculation of a full filtration service budget. It is clear, however, that given this low filtration capacity, current efforts at mangrove reforestation are unlikely to create an effective buffer for coastal eutrophication, but that nutrient input management will be required.

Table 3. Mangrove filtration efficiency for $\mathrm{NO}_{3}{ }^{-}$and $\mathrm{PO}_{4}{ }^{3-}$ relative to land-derived riverine input, based on daily fluxes and a mangrove area of 515 ha. Daily nutrient inputs from Kaiser (unpublished [124], but see [50] for seasonal values).

\begin{tabular}{ccccc}
\hline & & River Discharge & Shrimp Pond Effluents & Mangrove Filtration \\
\hline $\mathrm{NO}_{3}{ }^{-}$ & {$\left[10^{3}\right.$ mol $\cdot$ day $\left.^{-1}\right]$} & 2007.8 & 5.3 & -9.6 to -1.4 \\
& \% of total input & 99.7 & 0.3 & -0.1 to -0.5 \\
$\mathrm{PO}_{4}{ }^{3-}$ & {$\left[10^{3}\right.$ mol $\cdot$ day $\left.^{-1}\right]$} & 33.3 & 0.9 & -0.41 to -0.40 \\
& \% of total input & 97.4 & 2.6 & -1.2 to -1.2 \\
\hline
\end{tabular}

\section{Conclusions}

In this study we employed pore water concentration profiles, intact sediment core incubations, and tidal sampling of estuarine waters and mangrove effluents to investigate nutrient dynamics in a subtropical mangrove forest. Results show that the combination of methods aids the understanding of processes at different system levels.

Mangrove sediments are a source for $\mathrm{NH}_{4}{ }^{+}$and $\mathrm{Si}$ due to the exchange of $\mathrm{NH}_{4}{ }^{+}$- and Si-enriched pore waters across the sediment-water interface. Enhanced demand for oxidizing agents during early digenetic processes leads to sediment-directed fluxes of $\mathrm{NO}_{3}{ }^{-}$disclosing the mangrove sediments as a sink for nitrate. Although $\mathrm{PO}_{4}{ }^{3-}$ is released into the pore water during sedimentary organic matter degradation processes, enhanced $\mathrm{PO}_{4}{ }^{3-}$ utilization by benthic microalgae and mangrove trees may make the mangrove a net sink for $\mathrm{PO}_{4}{ }^{3-}$. The difference in pore water fluxes expected from concentration profiles and measured total benthic fluxes indicates that sub-surface nutrient processing does directly translate into sediment-water exchange, probably due to mediation by surface microorganisms.

The total filtration capacity of the Nanliu mangrove is low due to the small forest area and strong anthropogenic inputs. Thus, coastal nutrient management needs to concentrate on reduction of nutrient inputs, mainly from excessive fertilization in agriculture but with additional focus on growing aquaculture.

While seasonal climatic variability influences the magnitude of sedimentary processes, storm events cause a release of nutrients from pore waters during sediment displacement and ventilation of the surface sediment, inducing changes in sedimentary redox processes, which may lead to the reversion of benthic flux directions. The influence of such extreme events may persist longer for redox-sensitive nutrients like $\mathrm{NO}_{3}{ }^{-}$and $\mathrm{NH}_{4}{ }^{+}$than for $\mathrm{Si}$. The physical redistribution of sediments may also enhance the transport of organic matter into deeper sediment layers. However, the mechanism of organic matter transport and burial in mangrove sediments has not been part of this study and deserves its own research focus. Future studies should also aim to investigate individual processes causing observed nutrient fluxes and include wider spatiotemporal resolution in order to enhance the quality of filtration budgets. 


\section{Acknowledgements}

We thank the students Sun Ting and Julia Lange, as well as ZMT technician Christina Staschok for assistance during field work. We owe thanks to staff of the GMRC, particularly Dai Peijian, He Binyuan, and Lai Tinghe. For support in the lab we thank Matthias Birkicht and Dorothee Dasbach of the ZMT as well as Katrin Müller and Ines Scherff of the IOW. We also thankfully acknowledge comments by Karsten Lettmann on the application of the REC model. Comments from Matthias Zabel and anonymous reviewers on an earlier version helped in preparing this final manuscript. This research project was funded by the German Federal Ministry for Education and Research (BMBF; Project No.: 03 F 0607 B).

\section{Author Contributions}

David Kaiser, Daniela Unger, and Bing Yan conducted fieldwork and the laboratory experiment. Nicole Kowalski and Michael E Böttcher performed sample analyses. All authors discussed the results. David Kaiser wrote the main body of the text, with ample comments and remarks from all authors.

\section{Conflicts of Interest}

The authors declare no conflict of interest.

\section{References}

1. Cloern, J.E. Our evolving conceptual model of the coastal eutrophication problem. Mar. Ecol. Prog. Ser. 2001, 210, 223-253.

2. Conley, D.J.; Schelske, C.L.; Stoermer, E.F. Modification of the Biogeochemical Cycle of Silica with Eutrophication. Mar. Ecol. Prog. Ser. 1993, 101, 179-192.

3. Hodgkiss, I.; Ho, K. Are changes in N:P ratios in coastal waters the key to increased red tide blooms? Hydrobiologia 1997, 352, 141-147.

4. Howarth, R.; Chan, F.; Conley, D.J.; Garnier, J.; Doney, S.C.; Marino, R.; Billen, G. Coupled biogeochemical cycles: Eutrophication and hypoxia in temperate estuaries and coastal marine ecosystems. Front. Ecol. Environ. 2011, 9, 18-26.

5. Officer, C.B.; Ryther, J.H. The Possible Importance of Silicon in Marine Eutrophication. Mar. Ecol. Prog. Ser. 1980, 3, 83-91.

6. Paerl, H.W. Coastal eutrophication and harmful algal blooms: Importance of atmospheric deposition and groundwater as "new" nitrogen and other nutrient sources. Limnol. Oceanogr. 1997, 42, 1154-1165.

7. Selman, M.; Greenhalgh, S.; Diaz, R.; Sugg, Z. Eutrophication and Hypoxia in Coastal Areas: A Global Assessment of the State of Knowledge. WRI Policy Note Eutrophication Hypoxia Coast. Areas 2008, 1, 1-6.

8. Turner, R.E.; Qureshi, N.; Rabalais, N.N.; Dortch, Q.; Justic, D.; Shaw, R.F.; Cope, J. Fluctuating silicate:nitrate ratios and coastal plankton food webs. Proc. Natl. Acad. Sci. USA 1998, 95, 13048-13051.

9. Larsen, M.C.; Webb, R.M.T. Potential Effects of Runoff, Fluvial Sediment, and Nutrient Discharges on the Coral Reefs of Puerto Rico. J. Coast. Res. 2009, 189-208. 
10. Corredor, J.E.; Howarth, R.W.; Twilley, R.R.; Morell, J.M. Nitrogen cycling and anthropogenic impact in the tropical interamerican seas. Biogeochemistry 1999, 46, 163-178.

11. Burford, M.A.; Alongi, D.M.; McKinnon, A.D.; Trott, L.A. Primary production and nutrients in a tropical macrotidal estuary, Darwin Harbour, Australia. Estuar. Coast. Shelf Sci. 2008, 79, 440-448.

12. Valiela, I.; Bowen, J.L.; York, J. Mangrove Forests: One of the World's Threatened Major Tropical Environments. BioScience 2001, 51, 807-815.

13. Polidoro, B.A.; Carpenter, K.E.; Collins, L.; Duke, N.C.; Ellison, A.M.; Ellison, J.C.; Farnsworth, E.J.; Fernando, E.S.; Kathiresan, K.; Koedam, N.E.; et al. The Loss of Species: Mangrove Extinction Risk and Geographic Areas of Global Concern. PLoS ONE 2010, 5, e10095.

14. Li, M.S.; Lee, S.Y. Mangroves of China: A brief review. For. Ecol. Manag. 1997, 96, 241-259.

15. Terada, K.; Koibuchi, Y.; Koibuchi, M. Comparison of material fluxes based on observations in different types of estuaries including mangrove area. In Proceedings of the 2010 AGU Ocean Sciences Meeting, Portland, OR, USA, 22-26 February 2010.

16. Adame, M.F.; Virdis, B.; Lovelock, C.E. Effect of geomorphological setting and rainfall on nutrient exchange in mangroves during tidal inundation. Mar. Freshw. Res. 2010, 61, 1197-1206.

17. Valiela, I.; Cole, M.L. Comparative Evidence that Salt Marshes and Mangroves May Protect Seagrass Meadows from Land-derived Nitrogen Loads. Ecosystems 2002, 5, 92-102.

18. Wang, M.; Zhang, J.; Tu, Z.; Gao, X.; Wang, W. Maintenance of estuarine water quality by mangroves occurs during flood periods: A case study of a subtropical mangrove wetland. Mar. Pollut. Bull. 2010, 60, 2154-2160.

19. Wu, Y.; Chung, A.; Tam, N.F.Y.; Pi, N.; Wong, M.H. Constructed mangrove wetland as secondary treatment system for municipal wastewater. Ecol. Eng. 2008, 34, 137-146.

20. Wu, Y.; Tam, N.F.Y.; Wong, M.H. Effects of salinity on treatment of municipal wastewater by constructed mangrove wetland microcosms. Mar. Pollut. Bull. 2008, 57, 727-734.

21. Rivera-Monroy, V.H.; Torres, L.A.; Bahamon, N.; Newmark, F.; Twilley, R.R. The Potential Use of Mangrove Forests as Nitrogen Sinks of Shrimp Aquaculture Pond Effluents: The Role of Denitrification. J. World Aquac. Soc. 1999, 30, 12-25.

22. Robertson, A.I.; Phillips, M.J. Mangroves as filters of shrimp pond effluent: Predictions and biogeochemical research needs. Hydrobiologia 1995, 295, 311-321.

23. Tam, N.F.Y.; Wong, Y.S. Retention of nutrients and heavy metals in mangrove sediment receiving wastewater of different strengths. Environ. Technol. 1993, 14, 719-729.

24. Ye, Y.; Tam, N.F.Y.; Wong, Y.S. Livestock Wastewater Treatment by a Mangrove Pot-cultivation System and the Effect of Salinity on the Nutrient Removal Efficiency. Mar. Pollut. Bull. 2001, 42, $512-520$.

25. Jørgensen, B. Bacteria and Marine Biogeochemistry. In Marine Geochemistry; Schulz, H.D., Zabel, M., Eds.; Springer: Berlin/Heidelberg, Germany, 2006; pp. 169-206.

26. Mortimer, R.J.G.; Krom, M.D.; Watson, P.G.; Frickers, P.E.; Davey, J.T.; Clifton, R.J. Sediment-Water Exchange of Nutrients in the Intertidal Zone of the Humber Estuary, UK. Mar. Pollut. Bull. 1999, 37, 261-279.

27. Nixon, S. Remineralization and nutrient cycling in coastal marine ecosystems. In Estuaries and Nutrients; Neilson, B.J., Cronin, L.E., Eds.; Humana Press: Clifton, NJ, USA, 1981; pp. 111-138. 
28. Alongi, D.M.; Ramanathan, A.L.; Kannan, L.; Tirendi, F.; Trott, L.A.; Bala Krishna Prasad, M. Influence of human-induced disturbance on benthic microbial metabolism in the Pichavaram mangroves, Vellar-Coleroon estuarine complex, India. Mar. Biol. 2005, 147, 1033-1044.

29. Berg, P.; Risgaard-Petersen, N.; Rysgaard, S. Interpretation of Measured Concentration Profiles in Sediment Pore Water. Limnol. Oceanogr. 1998, 43, 1500-1510.

30. Hansen, K.; Kristensen, E. The impact of the polychaete Nereis diversicolor and enrichment with macroalgal (Chaetomorpha linum) detritus on benthic metabolism and nutrient dynamics in organic-poor and organic-rich sediment. J. Exp. Mar. Biol. Ecol. 1998, 231, 201-223.

31. Kristensen, K.; Hansen, K. Transport of carbon dioxide and ammonium in bioturbated (Nereis diversicolor) coastal, marine sediments. Biogeochemistry 1999, 45, 147-168.

32. Nielsen, O.I.; Kristensen, E.; Macintosh, D.J. Impact of fiddler crabs (Uca spp.) on rates and pathways of benthic mineralization in deposited mangrove shrimp pond waste. J. Exp. Mar. Biol. Ecol. 2003, 289, 59-81.

33. Nordhaus, I.; Wolff, M.; Diele, K. Litter processing and population food intake of the mangrove crab Ucides cordatus in a high intertidal forest in northern Brazil. Estuar. Coast. Shelf Sci. 2006, 67, 239-250.

34. Xin, P.; Jin, G.; Li, L.; Barry, D.A. Effects of crab burrows on pore water flows in salt marshes. Adv. Water Resour. 2009, 32, 439-449.

35. Alongi, D.M.; Boto, K.G.; Tirendi, F. Effect of exported mangrove litter on bacterial productivity and dissolved organic carbon fluxes in adjacent tropical nearshore sediments. Mar. Ecol. Prog. Ser. 1989, 56, 133-144.

36. Bartoli, M.; Nizzoli, D.; Viaroli, P. Microphytobenthos activity and fluxes at the sediment-water interface: Interactions and spatial variability. Aquat. Ecol. 2003, 37, 341-349.

37. Lerat, Y.; Lasserre, P.; Corre, P. le Seasonal changes in pore water concentrations of nutrients and their diffusive fluxes at the sediment-water interface. J. Exp. Mar. Biol. Ecol. 1990, 135, 135-160.

38. Wolfe, C.I.; Hammond, D.E.; Schwartz, R.J. Evaluating the accuracy of core incubations to determine benthic fluxes of 222Rn, 228Ra, and 224Ra, measured in core incubations. In AGU Fall Meeting Abstracts; American Geophysical Union: Washington, DC, USA, 2009; Volume 1, p. 1184.

39. Ishii, Y.; Yabe, T.; Nakamura, M.; Amano, Y.; Komatsu, N.; Watanabe, K. Effect of Nitrate on Phosphorus Mobilization from Bottom Sediment in Shallow Eutrophic Lakes. J. Water Environ. Technol. 2009, 7, 163-176.

40. An, S.; Gardner, W.S. Dissimilatory nitrate reduction to ammonium (DNRA) as a nitrogen link, versus denitrification as a sink in a shallow estuary (Laguna Madre/Baffin Bay, Texas). Mar. Ecol. Prog. Ser. 2002, 237, 41-50.

41. Denis, L.; Grenz, C.; Alliot, É.; Rodier, M. Temporal variability in dissolved inorganic nitrogen fluxes at the sediment-water interface and related annual budget on a continental shelf (NW Mediterranean). Oceanol. Acta 2001, 24, 85-97.

42. Rowe, G.T.; Boland, G.S.; Phoel, W.C.; Anderson, R.F.; Biscaye, P.E. Deep-sea floor respiration as an indication of lateral input of biogenic detritus from continental margins. Deep Sea Res. Part II Top. Stud. Oceanogr. 1994, 41, 657-668. 
43. Orihel, D.M.; Rooney, R.C. A field-based technique for sediment incubation experiments. J. Limnol. 2012, 71, e25.

44. Cathalot, C.; Rabouille, C.; Pastor, L.; Deflandre, B.; Viollier, E.; Buscail, R.; Grémare, A.; Treignier, C.; Pruski, A. Temporal variability of carbon recycling in coastal sediments influenced by rivers: Assessing the impact of flood inputs in the Rhône River prodelta. Biogeosciences 2010, 7, 1187-1205.

45. Adame, M.; Lovelock, C. Carbon and nutrient exchange of mangrove forests with the coastal ocean. Hydrobiologia 2011, 663, 23-50.

46. Bouillon, S.; Dehairs, F.; Velimirov, B.; Abril, G.; Borges, A.V. Dynamics of organic and inorganic carbon across contiguous mangrove and seagrass systems (Gazi Bay, Kenya). J. Geophys. Res. 2007, 112, G02018.

47. Bouillon, S.; Middelburg, J.J.; Dehairs, F.; Borges, A.V.; Abril, G.; Flindt, M.R.; Ulomi, S.; Kristensen, E. Importance of intertidal sediment processes and porewater exchange on the water column biogeochemistry in a pristine mangrove creek (Ras Dege, Tanzania). Biogeosci. Discuss. 2007, 4, 317-348.

48. Dittmar, T.; Lara, R.J. Driving Forces Behind Nutrient and Organic Matter Dynamics in a Mangrove Tidal Creek in North Brazil. Estuar. Coast. Shelf Sci. 2001, 52, 249-259.

49. Committee of Annals of Chinese Estuaries. Annals of Chinese Estuaries; Ocean Press: Beijing, China, 1998; Volume 14.

50. Kaiser, D.; Unger, D.; Qiu, G.; Zhou, H.; Gan, H. Natural and human influences on nutrient transport through a small subtropical Chinese estuary. Sci. Total Environ. 2013, 450-451, 92-107.

51. Kaiser, D.; Unger, D.; Qiu, G. Particulate organic matter dynamics in coastal systems of the northern Beibu Gulf. Cont. Shelf Res. 2014, 82, 99-118.

52. Mortazavi, B.; Riggs, A.A.; Caffrey, J.M.; Genet, H.; Phipps, S.W. The Contribution of Benthic Nutrient Regeneration to Primary Production in a Shallow Eutrophic Estuary, Weeks Bay, Alabama. Estuar. Coasts 2012, 35, 862-877.

53. Grasshoff, K.; Ehrhardt, M.; Kremling, K. Methods of Seawater Analysis. Second, Revised and Extended Edition; Grasshoff, K.; Ehrhardt, M., Kremling, K., Eds.; Verlag Chemie: Deerfield Beach, FL, USA, 1983; Volume 2.

54. Kérouel, R.; Aminot, A. Fluorometric determination of ammonia in sea and estuarine waters by direct segmented flow analysis. Mar. Chem. 1997, 57, 265-275.

55. Alongi, D.M.; Sasekumar, A.; Tirendi, F.; Dixon, P. The influence of stand age on benthic decomposition and recycling of organic matter in managed mangrove forests of Malaysia. J. Exp. Mar. Biol. Ecol. 1998, 225, 197-218.

56. Alongi, D.M. Zonation and Seasonality of Benthic Primary Production and Community Respiration in Tropical Mangrove Forests. Oecologia 1994, 98, 320-327.

57. Boucher, G.; Clavier, J.; Garrigue, C. Oxygen and carbon dioxide fluxes at the water-sediment interface of a tropical lagoon. Mar. Ecol. Prog. Ser. 1994, 107, 185-193.

58. Alongi, D.M.; Wattayakorn, G.; Pfitzner, J.; Tirendi, F.; Zagorskis, I.; Brunskill, G.J.; Davidson, A.; Clough, B.F. Organic carbon accumulation and metabolic pathways in sediments of mangrove forests in southern Thailand. Mar. Geol. 2001, 179, 85-103. 
59. Alongi, D.M.; Christoffersen, P.; Tirendi, F. The influence of forest type on microbial-nutrient relationships in tropical mangrove sediments. J. Exp. Mar. Biol. Ecol. 1993, 171, 201-223.

60. Holmer, M.; Andersen, F.Ø.; Holmboe, N.; Kristensen, E.; Thongtham, N. Spatial and temporal variability in benthic processes along a mangrove-seagrass transect near the Bangrong Mangrove, Thailand. Wetl. Ecol. Manag. 2001, 9, 141-158.

61. Kristensen, E.; Andersen, F.Ø.; Kofoed, L.H. Preliminary assessment of benthic community metabolism in a south-east Asian mangrove swamp. Mar. Ecol. Prog. Ser. 1988, 48, 137-145.

62. Kristensen, E.; Andersen, F.; Holmboe, N.; Holmer, M.; Thongtham, N. Carbon and nitrogen mineralization in sediments of the Bangrong mangrove area, Phuket, Thailand. Aquat. Microb. Ecol. 2000, 22, 199-213.

63. Kristensen, E.; Devol, A.H.; Ahmed, S.I.; Saleem, M. Preliminary study of benthic metabolism and sulfate reduction in a mangrove swamp of the Indus Delta, Pakistan. Mar. Ecol. Prog. Ser. 1992, 90, 287-297.

64. Kristensen, E.; Holmer, M.; Bussarawit, N. Benthic Metabolism and Sulfate Reduction in a Southeast Asian Mangrove Swamp. Mar. Ecol. Prog. Ser. 1991, 73, 93-103.

65. Trott, L.A.; McKinnon, A.D.; Alongi, D.M.; Davidson, A.; Burford, M.A. Carbon and nitrogen processes in a mangrove creek receiving shrimp farm effluent. Estuar. Coast. Shelf Sci. 2004, 59, 197-207.

66. Gocke, K.; Vitola, M.; Rojas, G. Oxygen consumption patterns in a mangrove swamp on the Pacific coast of Costa Rica. Rev. Biol. Trop. 1981, 29, 143-154.

67. Golley, F.; Odum, H.T.; Wilson, R.F. The Structure and Metabolism of a Puerto Rican Red Mangrove Forest in May. Ecology 1962, 43, 9-19.

68. Alongi, D.M.; Pfitzner, J.; Trott, L.A.; Tirendi, F.; Dixon, P.; Klumpp, D.W. Rapid sediment accumulation and microbial mineralization in forests of the mangrove Kandelia candel in the Jiulongjiang Estuary, China. Estuar. Coast. Shelf Sci. 2005, 63, 605-618.

69. Alongi, D.M.; Carvalho, N.A.; Amaral, A.L.; Costa, A., da; Trott, L.; Tirendi, F. Uncoupled surface and below-ground soil respiration in mangroves: Implications for estimates of dissolved inorganic carbon export. Biogeochemistry 2011, 109, 151-162.

70. Alongi, D.M. The role of bacteria in nutrient recycling in tropical mangrove and other coastal benthic ecosystems. Hydrobiologia 1994, 285, 19-32.

71. Boynton, W.R.; Kemp, W.M. Nutrient regeneration and oxygen consumption by sediments along an estuarine salinity gradient. Mar. Ecol. Prog. Ser. 1985, 23, 45-55.

72. Chen, G.C.; Tam, N.F.Y.; Ye, Y. Spatial and seasonal variations of atmospheric $\mathrm{N}_{2} \mathrm{O}$ and $\mathrm{CO}_{2}$ fluxes from a subtropical mangrove swamp and their relationships with soil characteristics. Soil Biol. Biochem. 2012, 48, 175-181.

73. Rees, G.N.; Bowen, P.M.; Watson, G.O. Variability in benthic respiration in three southeastern Australian lowland rivers. River Res. Appl. 2005, 21, 1147-1156.

74. Zimmerman, A.R.; Benner, R. Denitrification, nutrient regeneration and carbon mineralization in sediments of Galveston Bay, Texas, USA. Mar. Ecol. Prog. Ser. 1994, 114, 275-288.

75. Al-Raei, A.; Bosselmann, K.; Böttcher, M.; Hespenheide, B.; Tauber, F. Seasonal dynamics of microbial sulfate reduction in temperate intertidal surface sediments: Controls by temperature and organic matter. Ocean Dyn. 2009, 59, 351-370. 
76. Pamatmat, M.M. Ecology and Metabolism of a Benthic Community on an Intertidal Sandflat. Int. Rev. Gesamten Hydrobiol. Hydrogr. 1968, 53, 211-298.

77. Pomeroy, L.R. Algal productivity in salt marshes of Georgia. Limnol. Oceanogr. 1959, 386-397.

78. Guillén, J.; Bourrin, F.; Palanques, A.; Durrieu de Madron, X.; Puig, P.; Buscail, R. Sediment dynamics during wet and dry storm events on the Têt inner shelf (SW Gulf of Lions). Mar. Geol. 2006, 234, 129-142.

79. Smith, T.J.; Anderson, G.H.; Tiling, G. A tale of two storms: Surges and sediment deposition from Hurricanes Andrew and Wilma in Florida's southwest coast mangrove forests. Sci. Storms USGS Response Hurric. 2005 2005, 1, 169-174.

80. Souza, M.; Gomes, V.; Freitas, S.; Andrade, R.; Knoppers, B. Net Ecosystem Metabolism and Nonconservative Fluxes of Organic Matter in a Tropical Mangrove Estuary, Piauí River (NE of Brazil). Estuar. Coasts 2009, 32, 111-122.

81. Jørgensen, B.B. Bacterial sulfate reduction within reduced microniches of oxidized marine sediments. Mar. Biol. 1977, 41, 7-17.

82. Bouillon, S.; Borges, A.V.; Castañeda-Moya, E.; Diele, K.; Dittmar, T.; Duke, N.C.; Kristensen, E.; Lee, S.Y.; Marchand, C.; Middelburg, J.J.; et al. Mangrove production and carbon sinks: A revision of global budget estimates. Glob. Biogeochem. Cycles 2008, 22, 1-12.

83. Maher, D.T.; Eyre, B.D. Benthic fluxes of dissolved organic carbon in three temperate Australian estuaries: Implications for global estimates of benthic DOC fluxes. J. Geophys. Res. 2010, 115, G04039, doi:10.1029/2010JG001433.

84. Stanley, S.O.; Boto, K.G.; Alongi, D.M.; Gillan, F.T. Composition and bacterial utilization of free amino acids in tropical mangrove sediments. Mar. Chem. 1987, 22, 13-30.

85. Ziegler, S.; Benner, R. Dissolved organic carbon cycling in a subtropical seagrass-dominated lagoon. Mar. Ecol. Prog. Ser. 1999, 180, 149-160.

86. Alongi, D.M. The dynamics of benthic nutrient pools and fluxes in tropical mangrove forests. J. Mar. Res. 1996, 54, 123-148.

87. Alongi, D.M. Present state and future of the world's mangrove forests. Environ. Conserv. 2002, 29, 331-349.

88. Davis, S., III; Childers, D.; Day, J.; Rudnick, D.; Sklar, F. Wetland-water column exchanges of carbon, nitrogen, and phosphorus in a southern Everglades dwarf mangrove. Estuar. Coasts 2001, 24, 610-622.

89. Rivera-Monroy, V.H.; Day, J.W.; Twilley, R.R.; Vera-Herrera, F.; Coronado-Molina, C. Flux of Nitrogen and Sediment in a Fringe Mangrove Forest in Terminos Lagoon, Mexico. Estuar. Coast. Shelf Sci. 1995, 40, 139-160.

90. Rivera-Monroy, V.H.; Twilley, R.R. The Relative Role of Denitrification and Immobilization in the Fate of Inorganic Nitrogen in Mangrove Sediments (Terminos Lagoon, Mexico). Limnol. Oceanogr. 1996, 41, 284-296.

91. Rivera-Monroy, V.H.; Twilley, R.R.; Boustany, R.G.; Day, J.W.; Vera-Herrera, F.; del Carmen Ramirez, M. Direct denitrification in mangrove sediments in Terminos Lagoon, Mexico. Mar. Ecol. Prog. Ser. 1995, 126, 97-109. 
92. Lorenzen, J.; Larsen, L.H.; Kjær, T.; Revsbech, N.P. Biosensor Determination of the Microscale Distribution of Nitrate, Nitrate Assimilation, Nitrification, and Denitrification in a Diatom-Inhabited Freshwater Sediment. Appl. Environ. Microbiol. 1998, 64, 3264-3269.

93. Fernandes, S.O.; Michotey, V.D.; Guasco, S.; Bonin, P.C.; Loka Bharathi, P.A. Denitrification prevails over anammox in tropical mangrove sediments (Goa, India). Mar. Environ. Res. 2012, 74, 9-19.

94. Meyer, R.L.; Allen, D.E.; Schmidt, S. Nitrification and denitrification as sources of sediment nitrous oxide production: A microsensor approach. Mar. Chem. 2008, 110, 68-76.

95. Cornwell, J.C.; Kemp, W.M.; Kana, T.M. Denitrification in coastal ecosystems: Methods, environmental controls, and ecosystem level controls, a review. Aquat. Ecol. 1999, 33, 41-54.

96. Deek, A.; Emeis, K.; van Beusekom, J. Nitrogen removal in coastal sediments of the German Wadden Sea. Biogeochemistry 2012, 108, 467-483.

97. Gardner, W.; McCarthy, M. Nitrogen dynamics at the sediment-water interface in shallow, sub-tropical Florida Bay: Why denitrification efficiency may decrease with increased eutrophication. Biogeochemistry 2009, 95, 185-198.

98. Bellos, D.; Sawidis, T.; Tsekos, I. Nutrient chemistry of River Pinios (Thessalia, Greece). Environ. Int. 2004, 30, 105-115.

99. Bu, H.; Meng, W.; Zhang, Y. Nitrogen pollution and source identification in the Haicheng River basin in Northeast China. Sci. Total Environ. 2011, 409, 3394-3402.

100. Falco, S.; Niencheski, L.F.; Rodilla, M.; Romero, I.; Gonzáez del Río, J.; Sierra, J.P.; Mösso, C. Nutrient flux and budget in the Ebro estuary. Estuar. Coast. Shelf Sci. 2010, 87, 92-102.

101. Liu, S.M.; Li, R.H.; Zhang, G.L.; Wang, D.R.; Du, J.Z.; Herbeck, L.S.; Zhang, J.; Ren, J.L. The impact of anthropogenic activities on nutrient dynamics in the tropical Wenchanghe and Wenjiaohe Estuary and Lagoon system in East Hainan, China. Mar. Chem. 2011, 125, 49-68.

102. Meybeck, M.; Dürr, H.H.; Vörösmarty, C.J. Global coastal segmentation and its river catchment contributors: A new look at land-ocean linkage. Glob. Biogeochem. Cycles 2006, 20, GB1S90, doi:10.1029/2005GB002540.

103. Brunet, R.C.; Garcia-Gil, L.J. Sulfide-induced dissimilatory nitrate reduction to ammonia in anaerobic freshwater sediments. FEMS Microbiol. Ecol. 1996, 21, 131-138.

104. Burgin, A.J.; Hamilton, S.K. Have we overemphasized the role of denitrification in aquatic ecosystems? A review of nitrate removal pathways. Front. Ecol. Environ. 2007, 5, 89-96.

105. Chong, L.S.; Prokopenko, M.G.; Berelson, W.M.; Townsend-Small, A.; McManus, J. Nitrogen cycling within suboxic and anoxic sediments from the continental margin of Western North America. Mar. Chem. 2012, 128-129, 13-25.

106. Gardner, W.S.; McCarthy, M.J.; An, S.; Sobolev, D.; Sell, K.S.; Brock, D. Nitrogen Fixation and Dissimilatory Nitrate Reduction to Ammonium (DNRA) Support Nitrogen Dynamics in Texas Estuaries. Limnol. Oceanogr. 2006, 51, 558-568.

107. Dong, L.F.; Sobey, M.N.; Smith, C.J.; Rusmana, I.; Phillips, W.; Stott, A.; Osborn, A.M.; Nedwella, D.B. Dissimilatory reduction of nitrate to ammonium, not denitrification or anammox, dominates benthic nitrate reduction in tropical estuaries. Limnol. Oceanogr. 2011, 51, 279-291. 
108. Pérez-Villalona, H.; Cornwell, J.C.; Ortiz-Zayas, J.R.; Cuevas, E. Sediment Denitrification and Nutrient Fluxes in the San José Lagoon, a Tropical Lagoon in the Highly Urbanized San Juan Bay Estuary, Puerto Rico. Estuar. Coasts 2015, doi:10.1007/s12237-015-9953-3.

109. Kartal, B.; Kuypers, M.M.M.; Lavik, G.; Schalk, J.; Op den Camp, H.J.M.; Jetten, M.S.M.; Strous, M. Anammox bacteria disguised as denitrifiers: Nitrate reduction to dinitrogen gas via nitrite and ammonium. Environ. Microbiol. 2007, 9, 635-642.

110. Rütting, T.; Boeckx, P.; Müller, C.; Klemedtsson, L. Assessment of the importance of dissimilatory nitrate reduction to ammonium for the terrestrial nitrogen cycle. Biogeosci. Discuss. 2011, 8 , 1169-1196.

111. Rysgaard, S.; Risgaard-Petersen, N.; Sloth, N.P. Nitrification, denitrification, and nitrate ammonification in sediments of two coastal lagoons in Southern France. Hydrobiologia 1996, 329, $133-141$.

112. Callender, E. Benthic phosphorus regeneration in the Potomac River Estuary. Hydrobiologia 1982, 91-92, 431-446.

113. Howarth, R.W. Nutrient Limitation of Net Primary Production in Marine Ecosystems. Annu. Rev. Ecol. Syst. 1988, 19, 89-110.

114. Froelich, P.N. Kinetic Control of Dissolved Phosphate in Natural Rivers and Estuaries: A Primer on the Phosphate Buffer Mechanism. Limnol. Oceanogr. 1988, 33, 649-668.

115. Guangxi Mangrove Research Center. Review of China National Data and Information-Final Report; Guangxi Mangrove Research Center: Beihai, China, 2004; p. 76.

116. Ullman, W.J.; Sandstrom, M.W. Dissolved nutrient fluxes from the nearshore sediments of Bowling Green Bay, central Great Barrier Reef Lagoon (Australia). Estuar. Coast. Shelf Sci. 1987, 24, 289-303.

117. Bauer, A.; Radziejewska, T.; Liang, K.; Kowalski, N.; Dellwig, O.; Bosselmann, K.; Stark, A.; Xia, Z.; Harff, J.; Böttcher, M.E.; et al. Regional differences of hydrographical and sedimentological properties in Beibu Gulf, South China Sea. J. Coast. Res. 2013, doi:10.2112/SI_66_5.

118. Henry, K.M.; Twilley, R.R. Exploring the effects of black mangrove (Avicennia germinans) expansions on nutrient cycling in smooth cordgrass (Spartina alterniflora) marsh sediments of southern Louisiana, USA. In AGU Fall Meeting Abstracts; American Geophysical Union: Washington, DC, USA, 2011; Volume 1, p. 0441.

119. Dittmar, T.; Lara, R.J.; Kattner, G. River or mangrove? Tracing major organic matter sources in tropical Brazilian coastal waters. Mar. Chem. 2001, 73, 253-271.

120. Boto, K.G.; Wellington, J.T. Seasonal variations in concentrations and fluxes of dissolved organic and inorganic materials in a tropical, tidally-dominated, mangrove waterway. Mar. Ecol. Prog. Ser. 1988, 50, 151-160.

121. Amatya, I.M.; Kansakar, B.R.; Tare, V.; Fiksdal, L. Impact of temperature on biological denitrification process. J. Inst. Eng. 2009, 7, 121-126.

122. Goñi, M.A.; Gordon, E.S.; Monacci, N.M.; Clinton, R.; Gisewhite, R.; Allison, M.A.; Kineke, G. The effect of Hurricane Lili on the distribution of organic matter along the inner Louisiana shelf (Gulf of Mexico, USA). Cont. Shelf Res. 2006, 26, 2260-2280.

123. Porter, R.P.; Mason, E.T.P.R.P.; Sanford, L.P. Effect of tidal resuspension on benthic-pelagic coupling in an experimental ecosystem study. Mar. Ecol. Prog. Ser. 2010, 413, 33-53. 
124. Kaiser, D. Leibniz Center for Tropical Marine Ecology, Bremen, Germany. Unpublished work, 2011

125. Ashton, E.C.; Hogarth, P.J.; Ormond, R. Breakdown of mangrove leaf litter in a managed mangrove forest in Peninsular Malaysia. Hydrobiologia 1999, 413, 77-88.

126. Moll, R. Impact of Mangroves and an Agriculture-Dominated Hinterland on the Carbon and Nutrient Biogeochemistry in the Segara Anakan Lagoon, Java, Indonesia. Ph.D. Thesis, University Bremen, Bremen, Germany, 2011.

127. Tam, N.F.Y.; Wong, Y.S.; Lan, C.Y.; Wang, L.N. Litter production and decomposition in a subtropical mangrove swamp receiving wastewater. J. Exp. Mar. Biol. Ecol. 1998, 226, 1-18.

128. Tam, N.F.Y.; Vrijmoed, L.L.P.; Wong, Y.S. Nutrient Dynamics Associated with Leaf Decomposition in a Small Subtropical Mangrove Community in Hong Kong. Bull. Mar. Sci. 1990, 47, 68-78.

129. Vouvé, F.; Guiraud, G.; Marol, C.; Girard, M.; Richard, P.; Laima, M.J.C. $\mathrm{NH}_{4}{ }^{+}$turnover in intertidal sediments of Marennes-Oléron Bay (France): Effect of sediment temperature. Oceanol. Acta 2000, 23, 575-584.

130. Chu, H.Y.; Tam, N.F.Y.; Lam, S.K. S.; Wong, Y.S. Retention of Pollutants by Mangrove Soil and the Effects of Pollutants on Kandelia Candel. Environ. Technol. 2000, 21, 755-764.

131. Feller, I.C.; McKee, K.L.; Whigham, D.F.; O’Neill, J.P. Nitrogen vs. phosphorus limitation across an ecotonal gradient in a mangrove forest. Biogeochemistry 2002, 62, 145-175.

132. Feller, I.C.; Whigham, D.F.; O’Neill, J.P.; McKee, K.L. Effects of nutrient enrichment on within-stand cycling in a mangrove forest. Ecology 1999, 80, 2193-2205.

133. Tam, N.F.Y.; Wong, Y.S. Retention of Wastewater-borne Nitrogen and Phosphorus in Mangrove Soils. Environ. Technol. 1996, 17, 851-859.

134. Jiang, L.M.; Chen, B.; Qiu, S.F. The Relationship of Silt Transportation and Ocean Dynamical Condition in Delta of Lianzhou Bay. J. Guangxi Acad. Sci. 2008, 24, 25-28.

(C) 2015 by the authors; licensee MDPI, Basel, Switzerland. This article is an open access article distributed under the terms and conditions of the Creative Commons Attribution license (http://creativecommons.org/licenses/by/4.0/). 